U.S. GEOLOGICAL SURVEY CIRCULAR 942

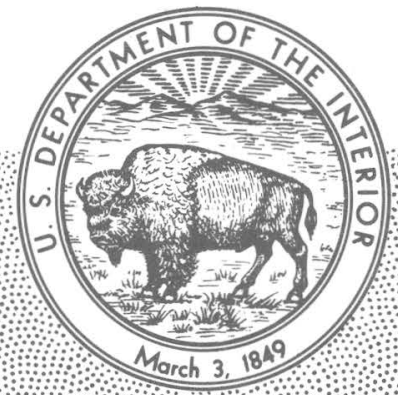

Nonprofit Sample and

Core Repositories

Open to the Public

in the United States 

NONPROFIT SAMPLE AND CORE REPOSITORIES OPEN TO THE PUBLIC IN THE UNITED STATES 


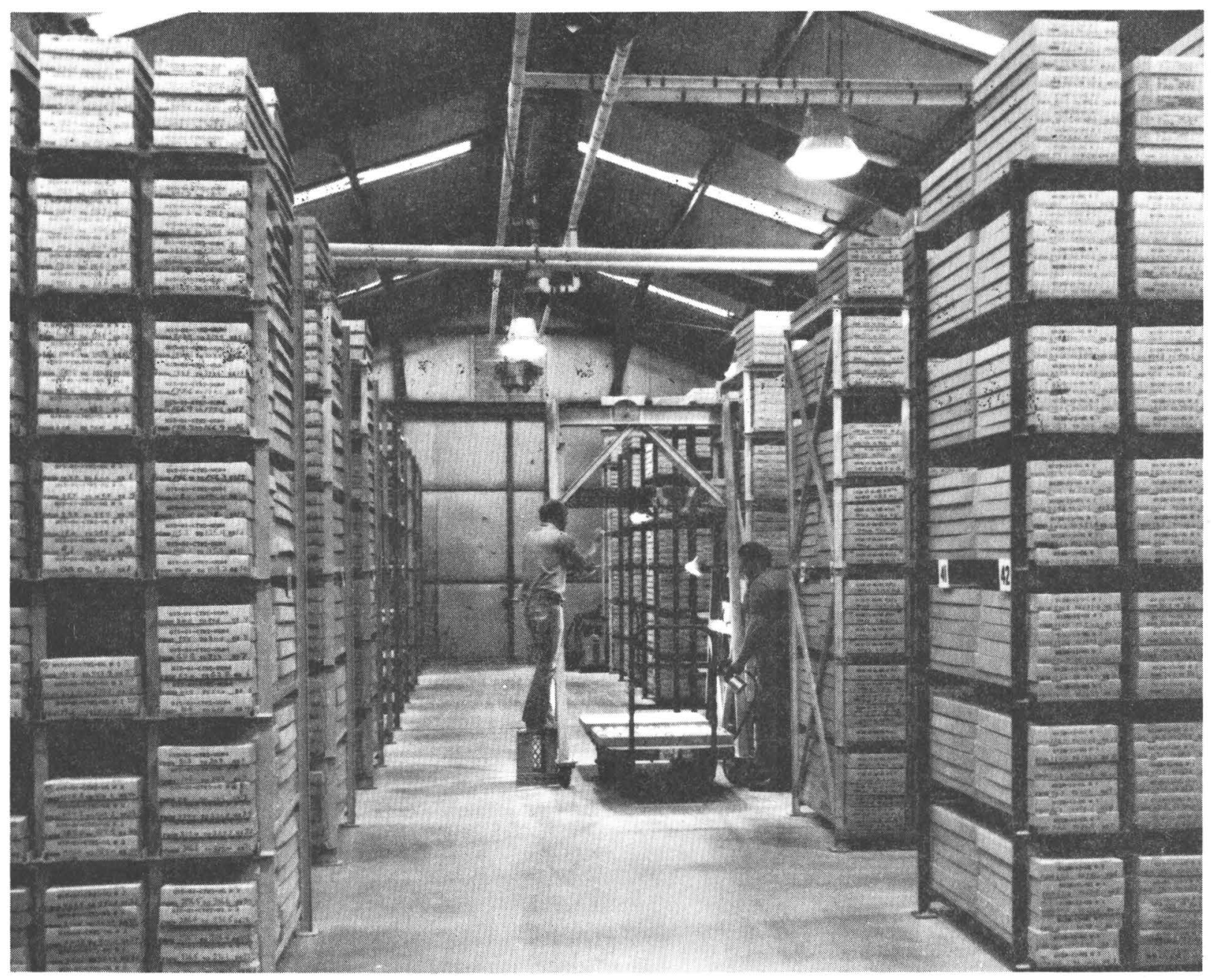

Interior of core-storage facility showing photography equipment in operation. Photograph courtesy of U.S. Geological Survey, Geological Data Center, Mercury, Nevada. 


\section{Nonprofit Sample and}

Core Repositories

Open to the Public

in the United States

By James W. Schmoker, Thomas C. Michalski, and Patricia B. Worl

U.S. GEOLOGICAL SURVEY CIRCULAR 942 


\section{United States Department of the Interior}

WILLIAM P. CLARK, Secretary

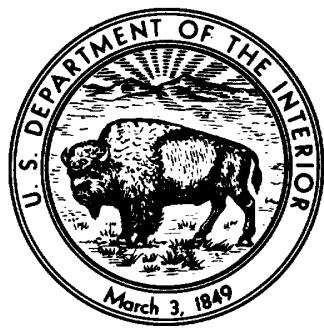

Geological Survey

Dallas L. Peck, Director 


\section{CONTENTS}

Introduction

References cited

Part I-Detailed descriptions of sample and core repositories ............

Alabama $\ldots \ldots$
Alaska $\ldots \ldots \ldots$$\ldots \ldots$

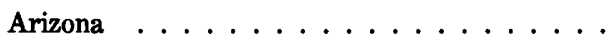

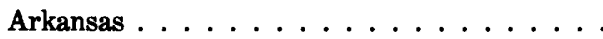

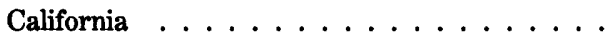

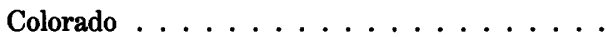

Delaware ...............

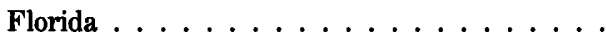

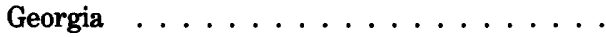

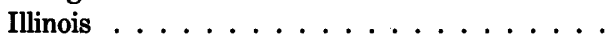

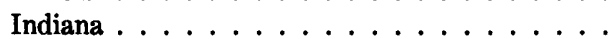

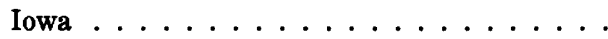

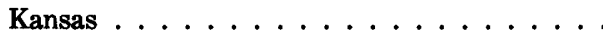

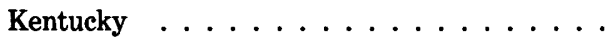

Maryland . . . . . . . . . . . .

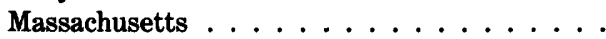

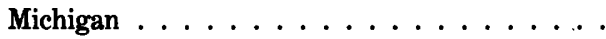

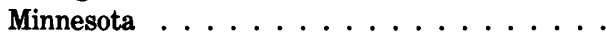

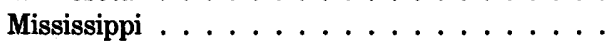

Missouri

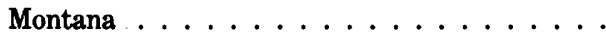

Nebraska ..............

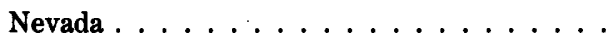

New Mexico ...............

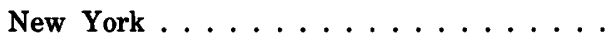

North Carolina ............

North Dakota ..............

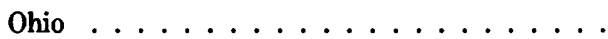

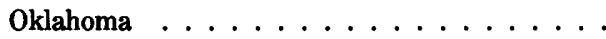

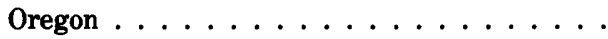

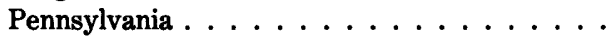

South Carolina ..............

South Dakota
Page

1 Part I-Detailed descriptions of sample and core

2

3

3

5-7

8,9

10

11,12

13

14

15,16

17

18

19

20

21, 22

23

24

25

26, 27

28,29

30

31

32,33

34

35

36

37-39

40

41

42,43

44

45

46

47

48

Page repositories-Continued

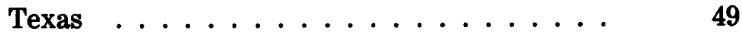

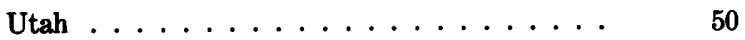

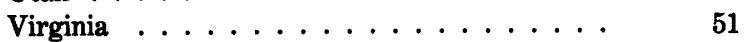

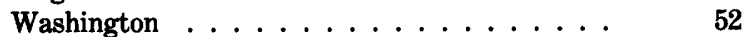

West Virginia ............... 53

Wisconsin ............... 54

Part II - Abridged descriptions of sample and core repositories ........................... 55

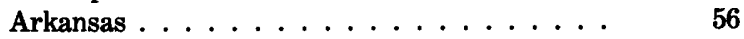

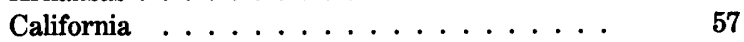

Colorado ................. 58,59

Florida . . . . . . . . . . . . 60,61

Hawaii ................ 62-64

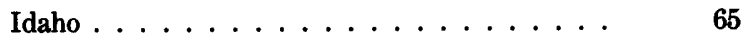

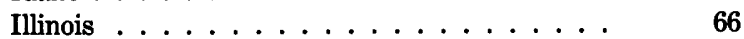

Louisiana . . . . . . . . . . . . . 67-69

Massachusetts .............. 70-74

Michigan . . . . . . . . . . . . $75-79$

Minnesota ............... 80, 81

Montana .................. 82

Nevada . . . . . . . . . . . . . . . . . . . 83

New Mexico ................ 84

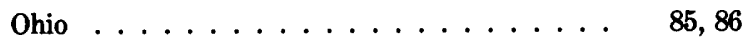

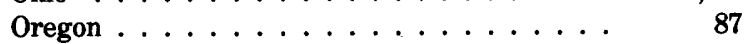

Pennsylvania . . . . . . . . . . . . $88-90$

Rhode Island ............... 91

Tennessee ................ 92,93

Texas .................... 94,95

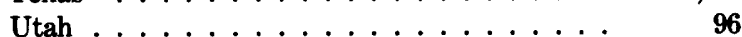

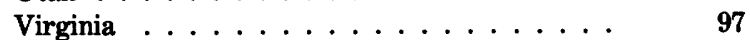

Washington ............... 98,99

Wisconsin ................ 100

Appendix. U.S. Army Corps of Engineers district offices .............. 101, 102 
$\therefore$. 


\title{
NONPROFIT SAMPLE AND CORE REPOSITORIES OPEN TO THE PUBLIC IN THE UNITED STATES
}

\author{
BY James W. Schmoker, Thomas C. Michalski, and Patricia B. Worl
}

\section{INTRODUCTION}

This directory presents user-oriented data on 96 publicly available, nonprofit repositories for samples and cores (including oceanographic collections) in the United States. Entries and descriptions are based on responses to a questionnaire mailed to each repository in late 1983 . The directory is an updated and expanded version of an earlier report (Schmoker and others, 1984).

Considerable effort was made to develop a comprehensive list of nonprofit sample and core repositories in the United States that are open to the public. The starting point was a directory of well-sample and core repositories by Fisher and Krupa (1977), which was in turn a revision of a directory by the American Association of Petroleum Geologists (1957). Additions, corrections, and deletions to these earlier reports were solicited from each State Geologist, from each state office of the Water Resources Division of the U.S. Geological Survey, from additional government agencies, from colleagues, and, finally, from the repository curators to whom questionnaires were directed.

Sample and core collections varying widely in content and usage are housed throughout the United States in facilities ranging from office cabinets to large specialized buildings, and selecting repositories from this series for inclusion in this directory was difficult. Several college and university collections that seemed more than a teaching tool are included. Agencies supervising major construction projects often retain projectrelated samples and cores for a period of time, and the more formal storage facilities of this type are described. Other repositories are included because their unique collections could be of particular value to people with specific research or educational needs. An Appendix lists all U.S. Army Corps of Engineers district offices, most of which maintain construction-related cores in storage.

Repository descriptions are somewhat arbitrarily grouped into two parts in this directory. The assignment to Part I or Part II should not be interpreted as relating to the quality or significance of a particular collection, but rather is based on the facility's main purpose as perceived from the questionnaire response. Facilities included in Part I seem designed primarily to serve the earth-science community in general. Facilities included in Part II seem intended primarily to serve the administrating agency, but do admit individuals who have a legitimate interest in the collection. We hope that the information given for repositories in both sections is sufficient to form a realistic picture of each facility.

As early as 1948, the American Association of Petroleum Geologists recognized that better collection and preservation of well samples and cores were needed, and in 1953 a committee formed to study the problem concluded that samples and cores of fundamental scientific importance had been lost in the past and were continuing to be lost (Lonsdale, 1953). Since then, geologists probably have become increasingly aware that there is no substitute for studying the actual subsurface material, and progress has been made in the permanent preservation of such material. Evidence for progress includes a strong regional network 
of repositories in western Canada (Pow, 1969), and recent publication of plans for core and sample preservation (Bureau of Mines, 1978; Davidson, 1981; Heiken and Goff, 1981; Goff and Heiken, 1982).

However, the questionnaire responses on which this report is based clearly show that samples and cores that are unique and that may at some time in the future have a value that cannot now be predicted are still being lost. The utility of a repository is often not fully realized by the administrating agency, and many sample and core storage facilities in the United States, taken as a whole, are understaffed and underfunded.

We hope that the information collected here will increase awareness of core and sample collections, and will facilitate the utilization, preservation, and curation of subsurface material.

\section{REFERENCES CITED}

American Association of Petroleum Geologists, 1957, Sample and core repositories of the United States, Alaska, and Canada: American Association of Petroleum Geologists, Committee on Preservation of Samples and Cores, $29 \mathrm{p}$.
Davidson, E. D., Jr., 1981, A look at core and sample libraries: Bureau of Economic Geology, The University of Texas at Austin, 4 p. and Appendix.

Fisher, C. K., and Krupa, M. P., 1977, Well-sample and core repositories of the United States and Canada: U.S. Geological Survey Open-File Report 77-567, 73 p.

Goff, Sue, and Heiken, Grant, eds., 1982, Workshop on core and sample curation for the National Continental Scientific Drilling Program: Los Alamos National Laboratory, May 5-6, 1981, LA-9308-C, 31 p.

Heiken, Grant, and Goff, Sue, 1981, Continental Scientific Drilling Program curatorial needs: Los Alamos Scientific Laboratory LA-8726-MS, 294 p.

Lonsdale, J. T., 1953, On the preservation of well samples and cores: Shale Shaker, v. 3, no. 7, p. 4.

Pow, J. R., 1969, Core and sample storage in western Canada: Bulletin of Canadian Petroleum Geology, v. 17, no. 4, p. 362-369.

Schmoker, J. W., Michalski, T. C., and Worl, P. B., 1984, Addresses, telephone numbers, and brief descriptions of publicly available, nonprofit sample and core repositories of the United States: U.S. Geological Survey Open-File Report 84-333, 13 p.

U.S. Bureau of Mines, 1978, CORES operations manual; Bureau of Mines core repository system: U.S. Bureau of Mines Information Circular IC 8784, 118 p. 


\section{PART I}

Detailed descriptions of sample and core repositories, by State, in the United States. These facilities serve the earth-science community in general. 
Name, Mailing Address, Telephone

Geological Survey of Alabama and State Oil and Gas Board Sample and Core Library

P.0. Drawer 0

University, AL 35486

205-349-2852

\section{Location or Street Address}

420 Hackberry Lane

University of Alabama Campus

Tuscaloosa, AL

Hours

$8: 00-12: 00,1: 00-5: 00$

Monday through Friday

Advance notice necessary

\section{Purpose of Wells (Holes)}

0 il and gas: 85 percent

Water: $\quad 10$ percent

Coal: $\quad 2$ percent

Mining: $\quad 2$ percent

Construction: 1 percent

\section{Area Represented}

Alabama: $\quad 100$ percent

\section{Collection Size}

Core: Less than 50 locations

Core chips: 500-2,000 locations

Cuttings: $\quad 2,000-10,000$ locations

Growth rate: 250 locations per year

\section{Catalog}

Information is on index cards and lists, and includes location, formation name, depth, type of sample, and footage represented. Catalog is not available for distribution.

\section{Additional Information Available}

Logs, analyses. Call for details.

\section{Facilities and Services}

Facility occupies 12,250 square feet in masonry building with heat, electricity, telephone, and restrooms. Examination room is 150 square feet with kinocular and petrographic microscopes, and testing chemicals. Retrieval and replacement of material are provided.

\section{Curation Policy}

User fees: No

Sampling of material: Under some circumstances. Call for details.

Loan of material: No

Facility is accepting new material; companies drilling oil and gas wells must submit cuttings and cores. Material can be kept confidential for 6 months. 
Name, Mailing Address, Telephone

U.S. Geological Survey

Branch of Alaskan Geology

Alaska Core Library

4200 University Drive

Anchorage, AK 99508

907-786-7432

\section{Location or Street Address}

132 Manor

Government Hill

Anchorage, AK

Hours

By appointment

Purpose of Wells (Holes)

0 il and gas: 100 percent

Area Represented

Alaska: $\quad 100$ percent

\section{Collection Size}

Core: $\quad 50-500$ locations

Core chips: Not reported

Cuttings: Less than 500 locations

Growth rate: None

\section{Catalog}

Information is on index cards, and includes location, type of sample, and footage represented. Catalog is not available for distribution.

\section{Additional Information Available}

Photographs, logs, analyses (all limited in number). Call for details.

\section{Facilities and Services}

Facility occupies 5,000 square feet in wood building with heat, electricity, telephone, and restrooms. Examination room is 200 square feet with binocular microscopes. No user services are provided.

\section{Curation Policy}

User fees: No

Sampling of material: No

Loan of material: Very restricted. Call for details.

Collection is static, but facility would accept new material if offered.

\section{Remarks}

Collection will probably be moved to new State facility in Eagle River, which is presently under construction. 


\section{ALASKA}

Name, Mailing Address, Telephone

Alaska Oil and Gas Conservation

Commission

Well Sample and Core Library

3001 Porcupine Drive

Anchorage, AK 99501

907-279-1433

\section{Location or Street Address}

Same as above

\section{Hours}

$8: 00-4: 30$

Monday through Friday

Purpose of Wells (Holes)

Oil and gas: 100 percent

Area Represented

Alaska: $\quad 100$ percent

\section{Collection Size}

Core: Less than 50 locations

Core chips: 50-500 locations

Cuttings: $\quad 500-2,000$ locations

Growth rate: 30 locations per year
Catalog

Information is on lists and computer data base, and includes type of sample and footage represented. Catalog is available for distribution.

\section{Additional Information Available}

Logs, analyses, thin sections, extensive geochemical reports. Call for details.

\section{Facilities and Services}

Facility occupies 1,100 square feet in masonry building with heat, electricity, telephone, and restrooms. Examination room is 480 square feet (carpeted), with no equipment available. Retrieval and replacement of material are provided.

\section{Curation Policy}

User fees: No

Sampling of material: Yes (for slides and analyses only)

Loan of material: No

Facility is accepting new material; State receives cuttings from all exploratory wells and selected development wells. Material can be kept confidential for 25 months.

\section{Remarks}

Collection includes more than 40,000 special slides. In addition to thin sections, there are microfossil, heavy-mineral, kerogen, vitrinitereflectance, and clay-mineral slides. Descriptive literature is available. 
Name, Mailing Address, Telephone

Department of Natural Resources

Division of Geological and

Geophysical Surveys

Pouch 7-208

Anchorage, AK 99510

907-276-2653

\section{Location or Street Address}

Fish Hatchery Road

Eagle River, AK

\section{Hours}

$8: 00-4: 30$

Monday through Friday

\section{Purpose of Wells (Holes)}

Oil and gas: 90 percent

Coal: 4 percent

Mining: $\quad 4$ percent

Other: $\quad 2$ percent

\section{Area Represented}

Alaska:

95 percent

\section{Collection Size}

Core: Not known at present

Core chips: Not known at present

Cuttings: Not known at present

Growth rate: Not known at present

\section{Catalog}

Not available initially, but compilation is anticipated.

\section{Additional Information Available}

None available initially, but data accumulation is anticipated.

\section{Facilities and Services}

Facility will occupy 5,800 square feet in corrugated-steel building with heat, electricity, telephone, and restrooms. Examination room will be 600 square feet with no equipment available initially.

\section{Curation Policy}

User fees: No

Sampling of material: No

Loan of material: No

\section{Remarks}

Facility is presently under construction and is projected to be operational by early 1985. A building has been acquired, but considerable renovation is needed for use as a sample and core repository. 
Name, Mailing Address, Telephone

Arizona Oil and Gas Conservation Commission

1645 West Jefferson, Suite 420

Phoenix, AZ 85007

602-255-5161

Location or Street Address

Same as above

Hours

8:00-5:00

Monday through Friday

Advance notice necessary

\section{Purpose of Wells (Holes)}

$0 i l$ and gas: 67 percent

Stratigraphic: 19 percent

Water:

11 percent

Storage and

geothermal:

3 percent

Area Represented

Arizona: $\quad 100$ percent

\section{Collection Size}

Core: Not reported

Core chips: 50-500 locations

Cuttings: $\quad 500-2,000$ locations

Growth rate: 15 locations per year

\section{Catalog}

Information is on lists, and includes location, depth, type of sample, and footage represented. Catalog is available for distribution.

\section{Additional Information Available}

Logs. Call for details.

\section{Facilities and Services}

Facility occupies 600 square feet in concrete and masonry building with heat, air conditioning, electricity, and restrooms. Binocular microscopes are available. There is no separate examination room. Retrieval and replacement of material are provided.

\section{Curation Policy}

User fees: No

Sampling of material: Yes

Loan of material: No

Material can be kept confidential for. 6 months. 
ARIZONA

Name, Mailing Address, Telephone

Arizona Bureau of Geology and

Mineral Technology

845 North Park Avenue

Tucson, AZ 85719

602-621-7906

Location or Street Address

Same as above

Hours

8:00-5:00

Monday through Friday

Purpose of Wells (Holes)

Water: $\quad 70$ percent

0 il and gas: 15 percent

Mining: 15 percent

Area Represented

Arizona: 100 percent

\section{Collection Size}

Core: Less than 50 locations

Core chips: Not reported

Cuttings: $\quad 2,000-10,000$ locations

Growth rate: 25 locations per year
Catalog

Information is on index cards and lists, and includes location and footage represented. Partial lists are available for distribution.

\section{Additional Information Available}

Logs (limited in number). Call for details.

\section{Facilities and Services}

Facility occupies 1,000 square feet in concrete building with heat, air conditioning, electricity, telephone, and restrooms. Examination room (size not reported) has binocular microscopes. Retrieval and replacement of material are provided.

\section{Curation Policy}

User fees: No

Sampling of material: No

Loan of material: No

Facility is accepting new material; cuttings are received from city of Tucson (water wells) and new test wells in Arizona. Material can be kept confidential. 
Name, Mailing Address, Telephone

Arkansas Geological Commission

Well Sample Library

3815 West Roosevelt Road

Little Rock, AR 72204

501-371-1488

\section{Location or Street Address}

Same as above

\section{Hours}

$8: 00-4: 30$

Monday through Friday

\section{Purpose of Wells (Holes)}

Oil and gas: 90 percent

Water: $\quad 5$ percent

Mining: $\quad 5$ percent

Area Represented

Arkansas: 100 percent

\section{Collection Size}

Core: $\quad 50-500$ locations

Core chips: 50-500 locations

Cuttings: $\quad 2,000-10,000$ locations

Growth rate: 150 locations per year

\section{Catalog}

Information is on lists, and includes location, type of sample, and footage represented. Catalog is available for distribution.

\section{Additional Information Available}

Logs (limited in number). Call for details.

\section{Facilities and Services}

Facility occupies 2,100 square feet in masonry building with heat, electricity, telephone, and restrooms. Examination room is 120 square feet with binocular microscopes.

\section{Curation Policy}

User fees: No

Sampling of material: No

Loan of material: Yes

Facility is accepting new material. Material can be kept confidential. 


\section{CALIFORNIA}

Name, Mailing Address, Telephone

California Well Sample Repository 9001 Stockdale Highway

Bakersfield, CA 93309

805-833-2324

\section{Location or Street Address}

Same as above

\section{Hours}

$8: 00-5: 00$

Monday through Friday

Advance notice necessary

\section{Purpose of Wells (Holes)}

$0 i l$ and gas: 98 percent

Mining: 1 percent

Construction: 1 percent

\section{Area Represented}

California: 100 percent

\section{Collection Size}

Core: 50-500 locations

Core chips: 50-500 locations

Cuttings: $\quad 500-2,000$ locations

Growth rate: 1,100 locations per year

\section{Catalog}

Information is on lists, and includes location, formation name, depth, type of sample, and footage represented. Catalog is available for distribution.

\section{Additional Information Available}

Logs (limited in number). Call for details.

\section{Facilities and Services}

Facility occupies 6,000 square feet in corrugated-steel building with heat, air conditioning, electricity, and telephone. Binocular microscopes are available. There is no separate examination room. Retrieval, replacement, slabbing, and trimming of material are provided.

\section{Curation Policy}

User fees: Yes

Sampling of material: Yes

Loan of material: Yes

Facility is accepting all material offered. Material can be kept confidential for 6 months.

\section{Remarks}

Descriptive literature is available. 


\section{CALIFORNIA}

Name, Mailing Address, Telephone

University of California, San Diego Scripps Institution of Oceanography Deep Sea Drilling Project, A-031

West Coast Repository

La Jolla, CA 92093

$619-452-3528 / 3532$

Location or Street Address

Same as above

Hours

$8: 00-4: 30$

Monday through Friday

Advance notice necessary

Purpose of Wells (Holes)

Scientific research

(deep-sea drilling): 100 percent

Area Represented

Offshore: 100 percent

\section{Collection Size}

Core: $\quad 500-2,000$ locations

Core chips: Less than 50 locations

Cuttings: Less than 500 locations

Growth rate: None

\section{Catalog}

Information is on computer data base, and includes location, depth, type of sample, and footage represented. Catalog is available for distribution.

\section{Additional Information Available}

Photographs, logs (limited in number), analyses, thin sections, smear slides. Call for details.

\section{Facilities and Services}

Facility occupies wood building with heat, electricity, telephone, and restrooms. Examination room is 700 square feet with binocular and petrographic microscopes. Retrieval, replacement, slabbing, and trimming of material are provided.

\section{Curation Policy}

User fees: No

Sampling of material: Yes

Loan of material: Yes

Collection is static because drilling ceased at conclusion of Leg 96 .

Material is not kept confidential.

\section{Remarks}

Facility houses deep-sea drilling samples collected by GLOMAR CHALLENGER. Descriptive literature is available. Samples collected by GLOMAR CHALLENGER are also housed at Lamont-Doherty Geological

Observatory, New York (see New York). 
Name, Mailing Address, Telephone

U.S. Geological Survey

Core Library

Box 25046 Mail Stop 975

Denver Federal Center

Denver, C0 80225

303-234-5105

\section{Location or Street Address}

5293 Ward Road

Building A

Arvada, CO

\section{Hours}

8:00-4:30

Monday through Friday

Advance notice necessary

\section{Purpose of Wells (Holes)}

$0 i l$ and gas: 85 percent

Oil shale: 10 percent

Coal: $\quad 3$ percent

Mining: $\quad 2$ percent

\section{Area Represented}

$\begin{array}{lr}\text { Wyoming: } & 46 \text { percent } \\ \text { Montana: } & 23 \text { percent } \\ \text { Colorado: } & 15 \text { percent } \\ \text { North Dakota: } & 5 \text { percent } \\ \text { Other Western States : } & 11 \text { percent }\end{array}$ ( $\mathrm{AZ}, \mathrm{CA}, \mathrm{ID}, \mathrm{KS}, \mathrm{NE}, \mathrm{NV}, \mathrm{NM}, \mathrm{OK}$, SD, UT, WA)

\section{Collection Size}

Core: $\quad 2,000-10,000$ locations

Core chips: 50-500 locations

Cuttings: Less than 500 locations

Growth rate: 300 locations per year

\section{Catalog}

Information is on index cards and computer data base, and includes location, formation name, depth, type of sample, footage represented, and operator. Catalog is not available for distribution. A computer search can be made by catalog parameters singly or in combination.

\section{Additional Information Available}

Photographs, analyses and thin sections (both limited in number). Call for details.

\section{Facilities and Services}

Facility occupies 45,000 square feet in concrete building with heat, air conditioning, electricity, telephone, and restrooms. Examination room is 1,000 square feet with binocular and petrographic microscopes, trim saw and plugger, testing chemicals, camera, porosity-permeability equipment (USGS use only), and small reference library. Retrieval, replacement, slabbing, and trimming of material are provided.

\section{Curation Policy}

User fees: No

Sampling of material: If duplicate analyses and thin sections are returned to files.

Loan of material: No

Facility is accepting oil and gas cores from Rocky Mountain region; also material of research interest to USGS. Material can be kept confidential for 1 year.

\section{Remarks}

Descriptive literature is available. 


\section{DELAWARE}

Name, Mailing Address, Telephone

Delaware Geological Survey

University of Delaware

Newark, DE 19716

302-451-2833

\section{Location or Street Address}

Penny $\mathrm{Hall}$

Academy Street

University of Delaware

Newark, DE

\section{Hours}

$8: 00-4: 00$

Monday through Friday

Advance notice necessary

\section{Purpose of Wells (Holes)}

Water:

93 percent

Construction: 5 percent

$0 i 1$ and gas: 1 percent

Geothermal: 1 percent

\section{Area Represented}

Delaware:

99 percent

Maryland :

1 percent

\section{Collection Size}

Core: $\quad 50-500$ locations

Core chips: Less than 50 locations

Cuttings: $2,000-10,000$ locations

Growth rate: 100 locations per year
Catalog

Information is on lists, microfilm and (or) microfiche, and computer data base, and includes location, formation name, depth, type of sample, and footage represented. Catalog is not available for distribution.

\section{Additional Information Available}

Logs, analyses, thin sections. Call for details.

\section{Facilities and Services}

Facility occupies 2,000 square feet in concrete building with heat, air conditioning, electricity, telephone, and restrooms. Binocular and petrographic microscopes are available. There is no separate examination room. No user services are provided.

\section{Curation Policy}

User fees: No

Sampling of material: Yes

Loan of material: Yes

Facility is accepting new material. Material can be kept confidential. 
Name, Mailing Address, Telephone

Florida Geological Survey 903 West Tennessee Street

Tallahassee, FL 32304

904-488-9380

Location or Street Address

Same as above

\section{Hours}

8:00-5:00

Monday through Friday

Advance notice necessary

\section{Purpose of Wells (Holes)}

$\begin{array}{lr}\text { Water: } & 90 \text { percent } \\ \text { Oil and gas: } & 5 \text { percent } \\ \text { Stratigraphic: } & 4 \text { percent } \\ \text { Construction: } & 1 \text {. percent }\end{array}$

\section{Area Represented}

Florida:

Offshore Florida:

Alabama, Georgia:

\section{Collection Size}

Core: $\quad 50-500$ locations

Core chips: 50-500 locations

Cuttings: $\quad 10,000-50,000$ locations

Growth rate: 400 locations per year
Catalog

Information is on index cards and lists, and includes location, formation name, depth, type of sample, and footage represented. Catalog is not available for distribution.

\section{Additional Information Available}

Photographs, analyses, thin sections (all limited in number), logs. Call for details.

\section{Facilities and Services}

Facility occupies 2,766 square feet in concrete building with heat, air conditioning, electricity, telephone, and restrooms. Examination room is 200 square feet with binocular microscopes and testing chemicals. Retrieval and replacement of material are provided.

\section{Curation Policy}

User fees: No

Sampling of material: Under some circumstances. Call for details.

Loan of material: No

Facility is accepting new material from water wells, oil and gas tests within State, and cores drilled by Florida Geological Survey. Material from oil and gas tests can be kept confidential for 18 months. 
FLORIDA

Name, Mailing Address, Telephone

Florida State University

Department of Geology

Antarctic Marine Geology

Research Facility and Core Library

Tallahassee, FL 32306

904-644-2407

Location or Street Address

Same as above

Hours

8:00-5:00

Monday through Friday

Advance notice necessary

Purpose of Wells (Holes)

Scientific research

(primarily marine-sediment

coring and dredging): 100 percent

\section{Area Represented}

Antarctica and the

Southern Ocean:

99.9 percent

\section{Collection Size}

Core, dredge samples: 2,000-10,000

locations

Growth rate: 200-300 meters per year

\section{Catalog}

Information is in core-description volumes, and includes location, footage represented, lithology, and water depth. Core-description volumes, which are available for distribution, are complete reports describing cruise, sampling and handling procedures, and results of analyses.

\section{Additional Information Available}

Microscope slides, sample residues. Call for details.

\section{Facilities and Services}

Facility occupies 10,000 square feet in concrete building with refrigerated storage, heat, air conditioning, electricity, and telephone. Examination rooms (sizes not reported) have binocular and petrographic microscopes, trim saw and plugger, testing chemicals, cameras, and Antarctic reference library. Other equipment is. available within Department of Geology for limited use. Retrieval, replacement, slabbing, and trimming of material are provided.

\section{Curation Policy}

User fees: No

Sampling of material: Yes

Loan of material: Yes

Facility is accepting material as designated by National Science Foundation. Material is not kept confidential.

\section{Remarks}

Repository houses material collected through studies funded by National Science Foundation, Division of Polar Programs. Descriptive literature is available. 
Name, Mailing Address, Telephone

Georgia Geologic Survey

Well Cuttings and Core Library

19 Martin L. King, Jr., Drive, SW

4th Floor

Atlanta, GA 30334

404-656-3214

Location or Street Address

Same as above

\section{Hours}

$8: 00-4: 30$

Monday through Friday

By appointment

Purpose of Wells (Holes)

Water: $\quad 90$ percent

0 il and gas: 10 percent

Area Represented

Georgia: $\quad 100$ percent

\section{Collection Size}

Core: $\quad 50-500$ locations

Core chips: Less than 50 locations

Cuttings: $500-2,000$ locations

Growth rate: 10-15 locations per year
Catalog

Information is on lists, and includes location, type of sample, and footage represented. Catalog is not available for distribution.

\section{Additional Information Available}

File for each well containing all available information such as logs, correspondence, drilling and geological data, and test results.

\section{Facilities and Services}

Facility (size not reported) occupies masonry building with heat, air conditioning, electricity, telephone, and restrooms. Examination room (size not reported) has binocular microscopes. Retrieval and replacement of material are provided.

\section{Curation Policy}

User fees: No

Sampling of material: By permission from State Geologist. Call for details.

Loan of material: No

Facility is accepting new material from deeper wells ( +800 feet) or areas of sparse data. 0 il and gas cuttings can be kept confidential for 6 months. 
Name, Mailing Address, Telephone

Illinois State Geological Survey Geological Samples Library

Natural Resources Building

615 East Peabody Drive

Champaign, IL 61820

$217-333-3567 / 3664$

\section{Location or Street Address}

Natural Resources Studies Annex

Griffith at Hazelwood Drive

University of Illinois

Champaign, IL

\section{Hours}

8:00-5:00

Monday through Friday

\section{Purpose of Wells (Holes)}

$0 i 1$ and gas:

70 percent

Coal, water,

mining, construction: 30 percent

\section{Area Represented}

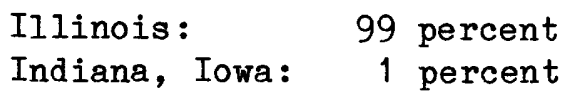

\section{Collection Size}

Core: $\quad 2,000-10,000$ locations Core chips: 2,000-10,000 locations Cuttings: More than 50,000 locations

Growth rate: 500 locations per year

\section{Catalog}

Information is on index cards, lists, and computer data base, and includes location, formation name, type of sample, and footage represented. Catalog is not available for distribution.

\section{Additional Information Available}

Logs and analyses are available at Geological Records Section. Call for details.

\section{Facilities and Services}

Facility occupies 18,000 square feet in concrete and masonry building with heat, air conditioning, electricity, telephone, and restrooms. Examination room is 240 square feet with binocular microscopes, testing chemicals, and ultraviolet light. Retrieval and replacement of material are provided.

\section{Curation Policy}

User fees: No

Sampling of material: Yes

Loan of material: No

Facility is accepting new material; cuttings are requested if drilling is more than 1 mile from existing well or deeper than nearby wells. Material can be kept confidential for 1 year. 
Name, Mailing Address, Telephone

Indiana Geological Survey

Core Library

611 North Walnut Grove

Bloomington, IN 47405

812-335-5412

\section{Location or Street Address}

12th and Woodlawn

Bloomington, IN

\section{Hours}

8:00-5:00

Monday through Friday

\section{Purpose of Wells (Holes)}

Oil and gas:

Coal:

Water:

Mining, construction:

97 percent

1 percent

1 percent

1 percent

Area Represented

Indiana :

Illinois :

Kentucky :

98 percent

1 percent

1 percent

\section{Collection Size}

Core: $\quad 500-2,000$ locations

Core chips: Less than 50 locations

Cuttings: $\quad 10,000-50,000$ locations

Growth rate: 180 locations per year

\section{Catalog}

Information is on index cards, and includes location, formation name, depth, type of sample, and footage represented. Catalog is not available for distribution.

\section{Additional Information Available}

Logs, analyses (limited in number), lithologic strip logs. Call for details.

\section{Facilities and Services}

Facility occupies 5,000 square feet in masonry building with heat, air conditioning, electricity, telephone, and restrooms. Examination room is 485 square feet with binocular microscopes. Retrieval, replacement, slabbing, and trimming of material are provided.

\section{Curation Policy}

User fees: No

Sampling of material: Yes

Loan of material: No

Facility is accepting new material. Material can be kept confidential. 
Name, Mailing Address, Telephone

Iowa Geological Survey

Oakdale Facility

123 North Capitol

Iowa City, IA 52242

319-353-6235

Location or Street Address

1 mile north of Interstate 80

(Exit 240)

Hours

$8: 00-4: 30$

Monday through Friday

Purpose of Wells (Holes)

Water: $\quad 75$ percent

Oil and gas: 10 percent

Coal: $\quad 5$ percent

Mining: $\quad 5$ percent

Stratigraphic: 4 percent

Construction: 1 percent

Area Represented

Iowa: $\quad 100$ percent

\section{Collection Size}

Core: $\quad 2,000-10,000$ locations

Core chips: Less than 50 locations

Cuttings: $\quad 10,000-50,000$ locations

Growth rate: 500-600 locations per year
Catalog

Information is on index cards and lists, and includes location, type of sample, and footage represented. Catalog is not available for distribution.

\section{Additional Information Available}

Logs, analyses, thin sections (limited in number). Call for details.

\section{Facilities and Services}

Facility occupies 11,000 square feet in corrugated-steel building with heat, air conditioning, electricity, telephone, and restrooms.

Examination room is 600 square feet with binocular microscopes, trim saw, testing chemicals, and camera.

Retrieval, replacement, slabbing, and trimming of material, and photostatic copying are provided.

\section{Curation Policy}

User fees: For copying; sample bags

Sampling of material: Yes

Loan of material: Yes

Facility is accepting new material from Iowa and surrounding area, and approved material of interest from outside this region to prevent loss. Call for details. Material can be kept confidential. 


\section{KANSAS}

Name, Mailing Address, Telephone

Kansas Geological Survey

1930 Constant Avenue, Campus West

Lawrence, KS 66044

913-864-4991

\section{Location or Street Address}

Same as above

Hours

8:00-5:00

Monday through Friday

Advance notice necessary

Purpose of Wells (Holes)

0il and gas: 90 percent

Coal: $\quad 7$ percent

Mining: 3 percent

Area Represented

Kansas: 99 percent

Nebraska, Colorado: 1 percent

\section{Collection Size}

Core: $\quad 2,000-10,000$ locations

Core chips: Less than 50 locations

Cuttings: None

Growth rate: 20 locations per year

\section{Catalog}

Information is on index cards, lists, and computer data base, and includes location, formation name, depth, and footage represented. Catalog is available for distribution.

\section{Additional Information Available}

Logs, analyses, thin sections. Call for details.

\section{Facilities and Services}

Facility occupies 4,800 square feet in corrugated-steel building with electricity. Examination room (size not reported) has binocular microscopes and trim saw. Limited services are provided. Call for details.

\section{Curation Policy}

User fees: No

Sampling of material: Yes

Loan of material: Yes

Facility is accepting some new material. Material can be kept confidential for 1 year, with 1 -year extension.

\section{Remarks}

Cuttings are housed at the Wichita Well Sample Library (see following page). 
Name, Mailing Address, Telephone

Kansas Geological Survey

Wichita Well Sample Library

Suite 103, Colorado Derby Building

Wichita, KS 67202

316-943-2343

Location or Street Address

4150 Monroe Street

Wichita, KS

Hours

8:00-5:00

Monday through Friday

Purpose of Wells (Holes)

0il and gas: 99 percent

Water, mining: 1 percent

\section{Area Represented}

Kansas :
Oklahoma, Nebraska: $\quad 97$ percent
$\quad 3$ percent

\section{Collection Size}

Core: None

Core chips: None

Cuttings: $\quad 10,000-50,000$ locations

Growth rate: 3,000 locations per year

\section{Catalog}

Information is on index cards, and includes location, footage represented, total depth, operator, and lease name. Catalog is not available for distribution.

\section{Additional Information Available}

Logs (on microfiche). Call for details.

\section{Facilities and Services}

Facility occupies 15,600 square feet in masonry and corrugated-steel building with heat, air conditioning, electricity, telephone, and restrooms. Examination room is 150 square feet with binocular microscopes, testing chemicals, uitraviolet light, microfiche viewer, and reference library. Retrieval and replacement of material are provided.

\section{Curation Policy}

User fees: Yes

Sampling of material: No

Loan of material: Yes

Facility is accepting new material; cuttings are requested if drilling is more than one-half mile from existing well or deeper than nearby wells. Material can be kept confidential for 1 year, with 1-year extension.

\section{Remarks}

Cores are housed at the Lawrence facility (see preceding page). Samples are shipped on loan anywhere in United States, and may be ordered by mail or telephone. Descriptive literature is avarilable. 


\section{KENTUCKY}

Name, Mailing Address, Telephone

Kentucky Geological Survey

Well Sample and Core Library

311 Breckingridge Hall

University of Kentucky

Lexington, KY 40506

606-257-1677

\section{Location or Street Address}

670 South Broadway

Lexington, $\mathrm{KY}$

\section{Hours}

$8: 00-4: 30$

Monday through Friday

\section{Purpose of Wells (Holes)}

0il and gas: 92 percent

Mining: $\quad 4$ percent

Coal: 2 percent

Stratigraphic,

other: 2 percent

\section{Area Represented}

Kentucky: $\quad 100$ percent

\section{Collection Size}

Core: $\quad 500-2,000$ locations

Core chips: Less than 50 locations

Cuttings: $\quad 10,000-50,000$ locations

Growth rate: 750 locations per year
Catalog

Information is on index cards and lists, and includes location, type of sample, and footage represented. Catalog is available for distribution.

\section{Additional Information Available}

Logs, thin sections. Call for details.

\section{Facilities and Services}

Facility occupies 13,500 square feet in wood building constructed in 1912 with heat, electricity, telephone, and restrooms. Examination room is 2,000 square feet with binocular microscopes, trim saw, and testing chemicals. Retrieval, replacement, slabbing, and trimming of material are provided.

\section{Curation Policy}

User fees: No

Sampling of material: Under strict controls. Call for details.

Loan of material: No

Facility is accepting new material; State law requires that cuttings from selected oil and gas tests be preserved. Material can be kept confidential for 1 year.

\section{Remarks}

Descriptive literature is available. 


\section{MARYLAND}

Name, Mailing Address, Telephone

Maryland Geological Survey

The Rotunda, Suite 440

711 West 40th Street

Baltimore, MD 21211

301-338-7105/7147

Location or Street Address

2100 Guilford Avenue

Baltimore, MD

Hours

$8: 30-4: 30$

Monday through Friday

Advance notice necessary

Purpose of Wells (Holes)

Water: $\quad 70$ percent

Oil and gas: 30 percent

Area Represented

Maryland: 100 percent

\section{Collection Size}

Core: $\quad 50-500$ locations

Core chips: Less than 50 locations

Cuttings: $\quad 500-2,000$ locations

Growth rate: 10-20 locations per year

\section{Catalog}

Information is on index cards and word processor, and includes location, type of sample, footage represented, owner, and State permit number. Catalog is available for distribution.

\section{Additional Information Available}

Logs. Call for details.

\section{Facilities and Services}

Facility occupies 1,000 square feet in masonry building with heat, air conditioning, electricity, telephone, and restrooms. Examination room is 120 square feet with binocular and petrographic microscopes. Retrieval and replacement of material are provided.

\section{Curation Policy}

User fees: No

Sampling of material: Very limited. Call for details.

Loan of material: By prior arrangement only. Call for details.

Facility is accepting new material. Material can be kept confidential. 
Name, Mailing Address, Telephone

Woods Hole Oceanographic

Institute

Sea Floor Samples Laboratory

McLean Building

Woods Hole, MA 02543

$617-548-1400$

\section{Location or Street Address}

Quissett Campus

Woods Hole, MA

\section{Hours}

8:00-5:00

Monday through Friday

Advance notice necessary

\section{Purpose of Wells (Holes)}

Scientific research

(marine-sediment

coring and dredging): 100 percent

\section{Area Represented}

Offshore: 100 percent

\section{Collection Size}

$\begin{array}{ll}\text { Core: } & \text { Not reported } \\ \text { Core chips: } & \text { Not reported } \\ \text { Cuttings: } & \text { Not reported }\end{array}$

Growth rate: 150 locations per year

\section{Catalog}

Information is on microfilm and (or) microfiche, and computer data base, and includes location, type of sample, footage represented, water depth, and description. Catalog is available for distribution. A computer search can be made by catalog parameters singly or in combination.

\section{Additional Information Available}

Photographs, logs, core analyses, thin sections, smear slides, carbonate analyses. Call for details.

\section{Facilities and Services}

Facility occupies 11,000 square feet in wood and masonry building with heat, air conditioning, electricity, telephone, and restrooms.

Examination room is 400 square feet with binocular and petrographic microscopes, trim saw and plugger, testing chemicals, camera, thin-section equipment, and other aids to sediment studies. Retrieval, replacement, slabbing, and trimming of material are provided.

\section{Curation Policy}

User fees: No

Sampling of material: Yes

Loan of material: Yes

Facility is accepting new material from scientific cruises and from other repositories. Collecting investigator can have proprietary usage for 2 years. 
Name, Mailing Address, Telephone

Department of Natural Resources

Michigan Geological Survey

Box 30028

Lansing, MI 48909

517-373-8220

Location or Street Address

Stevens T. Mason Building

Pine and Allegan Streets

Lansing, MI

Hours

8:00-5:00

Monday through Friday

Advance notice necessary

Purpose of Wells (Holes)

0 il and gas: 95 percent

Disposal: $\quad 5$ percent

\section{Area Represented}

Michigan:

98 percent

Ohio, Indiana,

Illinois, Ontario: 2 percent

\section{Collection Size}

Core: Not reported

Core chips: Less than 50 locations

Cuttings: $\quad 2,000-10,000$ locations

Growth rate: $35-40$ locations per year

\section{Catalog}

Information is on lists and computer data base, and includes location, formation name, type of sample, footage represented, State permit number, and lease name. Catalog is not available for distribution.

\section{Additional Information Available}

Logs, analyses (limited in number). Call for details.

\section{Facilities and Services}

Facility occupies 3,500 square feet in masonry building (State Record Center) with heat, electricity, and restrooms. Examination room is 400 square feet with no equipment available. Retrieval and replacement of material are provided.

\section{Curation Policy}

User fees: No

Sampling of material: No

Loan of material: Yes

Facility is accepting new material in accordance with State regulations and space limitations. Material can be kept confidential for 90 days following completion of well. 
Name, Mailing Address, Telephone

Department of Natural Resources Michigan Geological Survey 1990 U.S. \#41 South Marquette, MI 49855 906-226-7505

\section{Location or Street Address}

Same as above

\section{Hours}

$8: 00-4: 30$

Monday through Friday

By appointment

\section{Purpose of Wells (Holes)}

$\begin{array}{lr}\text { Mining: } & 50 \text { percent } \\ \text { Water: } & 47 \text { percent } \\ \text { Oil and gas : } & 3 \text { percent }\end{array}$

\section{Area Represented}

Michigan: $\quad 100$ percent

\section{Collection Size}

Core: $\quad 50-500$ locations

Core chips: Not reported

Cuttings: $\quad 500-2,000$ locations

Growth rate: 30 locations per year

\section{Catalog}

Information is on lists, and includes location, formation name, depth, and footage represented. Catalog is not available for distribution.

\section{Additional Information Available}

Logs, analyses (both limited in number). Call for details.

\section{Facilities and Services}

Facility occupies 4,000 square feet in wood and corrugated-steel building with heat, electricity, and telephone. Examination room is 400 square feet with binocular microscopes and trim saw. Retrieval, replacement, slabbing, and trimming of material are provided.

\section{Curation Policy}

User fees: No

Sampling of material: Yes

Loan of material: No

Facility is accepting cores from areas not represented in core collection. Material can be kept confidential in specific instances in accordance with Michigan's Freedom of Information Act. 


\section{MINNESOTA}

Name, Mailing Address, Telephone

Minnesota Department of Natural Resources

Minerals Division Drill Core Library 1525 East Third Avenue, Box 567

Hibbing, MN 55746

218-262-6767

\section{Location or Street Address}

Same as above

\section{Hours}

$8: 00-4: 00$

Monday through Friday

Advance notice necessary

Purpose of Wells (Holes)

$\begin{array}{ll}\text { Mining (iron): } & 80 \text { percent } \\ \begin{array}{l}\text { Mineral exploration } \\ \text { (nonferrous): }\end{array} & 20 \text { percent }\end{array}$

Area Represented

Minnesota: $\quad 100$ percent

\section{Collection Size}

Core: $\quad 2,000-10,000$ locations

Core chips: None

Cuttings: Less than 500 locations

Growth rate: 40 locations per year

\section{Catalog}

Information is on lists, microfilm and (or) microfiche, and computer data base, and includes location, formation name, depth, type of sample, and footage represented. Catalog is available for distribution.

\section{Additional Information Available}

Logs, analyses, thin sections (all for nonferrous material). Call for details.

\section{Facilities and Services}

Facility occupies 11,750 square feet in corrugated-steel building with electricity. Heated examination room is 315 square feet with binocular and petrographic microscopes, trim saw and plugger, and testing chemicals. No user services are provided.

\section{Curation Policy}

User fees: No

Sampling of material: Yes

Loan of material: Under some circumstances. Call for details.

Facility is accepting new material; State law requires that a one-quarter split of all exploratory drill core be submitted to State. Material submitted as required by State can be kept confidential. 
Name, Mailing Address, Telephone

U.S. Bureau of Mines

Twin Cities Core Storage Library

5629 Minnehaha Avenue South

Minneapolis, MN 55417

612-725-4535

Location or Street Address

Same as above

Hours

$8: 00-4: 30$

Monday through Friday

Advance notice necessary

Purpose of Wells (Holes)

Mining: $\quad 95$ percent

Construction: 5 percent

\section{Area Represented}

$\begin{array}{lr}\text { Minnesota: } & 35 \text { percent } \\ \text { Michigan: } & 29 \text { percent } \\ \text { Missouri: } & 8 \text { percent } \\ \text { Wisconsin: } & 7 \text { percent } \\ \text { New York: } & 6 \text { percent } \\ \text { Maine: } & 4 \text { percent } \\ \text { Virginia: } & 2 \text { percent }\end{array}$

Pennsylvania,

Alabama, Arkansas: 4 percent

17 other states: $\quad 5$ percent

\section{Collection Size}

Core: $\quad 2,000-10,000$ locations Core chips: Less than 50 locations Cuttings: Less than 500 locations

Growth rate: None

\section{Catalog}

Information is on lists, and includes location, type of sample, and footage represented. Catalog is not available for distribution.

\section{Additional Information Available}

None

\section{Facilities and Services}

Facility occupies 12,000 square feet in corrugated-steel building with heat, electricity, telephone, and restrooms. Examination room is 400 square feet with no equipment available.

\section{Curation Policy}

User fees: No

Sampling of material: No

Loan of material: No

Facility is not accepting new material. Material is not kept confidential.

\section{Remarks}

Collection formerly housed at Bureau's Denver, Colo., facility is being moved to the Twin Cities repository. Services to be provided are uncertain. Prospective users should inquire for details. 


\section{MISSISSIPPI}

Name, Mailing Address, Telephone

Mississippi Department of Natural

Resources

Bureau of Geology

P. 0. Box 5348

Jackson, MS 39216

$601-354-6228$

\section{Location or Street Address}

2525 North West Street

(Across from stadium)

Jackson, MS

Hours

8:00-5:00

Monday through Friday

\section{Purpose of Wells (Holes)}

0il and gas: 97 percent

Water: 3 percent

\section{Area Represented}

Mississippi: 99 percent

Alabama: $\quad 1$ percent

\section{Collection Size}

Core: $\quad 500-2,000$ locations

Core chips: Less than 50 locations

Cuttings: 2,000-10,000 locations

Growth rate: 150-175 locations per year

\begin{abstract}
Catalog
Information is on index cards and lists, and includes location, footage represented, and operator. Catalog is not available for distribution.
\end{abstract}

\section{Additional Information Available}

Logs, more than 20,000 scout cards. Call for details.

\section{Facilities and Services}

Facility occupies corrugated-steel building, with electricity, telephone, and restrooms. Heated and air-conditioned examination room is 100 square feet with binocular microscopes and trim saw. Slabbing and trimming of material are provided.

\section{Curation Policy}

User fees: No

Sampling of material: Yes

Loan of material: No

Facility is accepting new material; companies are asked to provide samples and cores from oil and gas tests. Material can be kept confidential. 
Name, Mailing Address, Telephone

Missouri Geological Survey

Core and Sample Library

111 Fairground Road

P.0. Box 250

Rolla, MO 65401

314-364-1752

\section{Location or Street Address}

Same as above

\section{Hours}

8:00-5:00

Monday through Friday

Advance notice preferred

\section{Purpose of Wells (Holes)}

$\begin{array}{lr}\text { Mining: } & 85 \text { percent } \\ \text { Oil and gas: } & 5 \text { percent } \\ \text { Coal: } & 5 \text { percent } \\ \text { Construction: } & 5 \text { percent }\end{array}$

Area Represented

$\begin{array}{lr}\text { Missouri : } & 95 \text { percent } \\ \text { Arkansas : } & 3 \text { percent } \\ \text { Kansas : } & 1 \text { percent } \\ \text { Oklahoma : } & 1 \text { percent }\end{array}$

\section{Collection Size}

Core: $\quad 500-2,000$ locations

Core chips: 50-500 locations

Cuttings: $500-2,000$ locations

Growth rate: 60 locations per year

\section{Catalog}

Information is on computer data base, and includes location, formation name, depth, type of sample, footage represented, and collar elevation. Catalog is available for distribution. A computer search can be made by depth, operator, location, or formation.

\section{Additional Information Available}

Logs, analyses, thin sections. Call for details.

\section{Facilities and Services}

Facility occupies 10,000 square feet in masonry building with electricity, telephone, and restrooms. Examination room is 100 square feet with

binocular microscopes. Retrieval and replacement of material are provided.

\section{Curation Policy}

User fees: No

Sampling of material: No

Loan of material: No

Facility is accepting new material. Material can be kept confidential for 3 years.

\section{Remarks}

Repository mails a quarterly fact sheet describing new material received. 
Name, Mailing Address, Telephone

Montana Board of Oil and Gas

Conservation

2535 St. Johns Avenue

Billings, MT 59102

406-656-0040

Location or Street Address

Same as above

Hours

8:00-5:00

Monday through Friday

Purpose of Wells (Holes)

Oil and gas: 100 percent

Area Represented

Montana:

100 percent

Collection Size

Core: None

Core chips: Not reported

Cuttings: $\quad 10,000-50,000$ locations

Growth rate: 225 locations per year

\section{Catalog}

Information is on index cards, and includes location, type of sample, and footage represented. Catalog is not available for distribution.

\section{Additional Information Available}

Not reported

\section{Facilities and Services}

Storage facility (size not reported) is part of office building, with heat, air conditioning, electricity, telephone, and restrooms. Examination room (size not reported) has a binocular microscope. No user services are provided.

\section{Curation Policy}

User fees: No

Sampling of material: No

Loan of material: No

Facility is accepting new material. Material is not kept confidential. 
Name, Mailing Address, Telephone

Montana Bureau of Mines and Geology Core Repository

Montana College of Mineral Science and Technology

Butte, MT 59701

406-496-4169

Location or Street Address

Butte Industrial Park

(Southwest of Butte airport)

Hours

$8: 00-5: 00$

Monday through Friday

Advance notice preferred

\section{Purpose of Wells (Holes)}

Mining:

Coal:

90 percent

10 percent

Area Represented

Montana:

100 percent

Collection Size

Core: $\quad 50-500$ locations

Core chips: Less than 50 locations

Cuttings: Less than 500 locations

Growth rate: 15 locations per year

\section{Catalog}

Collection is not cataloged.

Additional Information Available

Logs, analyses, thin sections. Call for details.

\section{Facilities and Services}

Facility occupies 3,200 square feet in corrugated-steel building with heat, electricity, and telephone. There is no examination room, and no equipment or user services are provided.

\section{Curation Policy}

User fees: No

Sampling of material: Yes

Loan of material: Yes

Facility is accepting new material;

accurate location description is required. Material can be kept confidential for 1 year.

\section{Remarks}

Facility described here has been acquired recently. There is now room for substantial expansion of collection. 
Name, Mailing Address, Telephone

Nebraska Geological Survey

Room 113, Nebraska Hall

University of Nebraska, Lincoln

Lincoln, NE 68588

402-472-3471

\section{Location or Street Address}

901 North 17th Street

Lincoln, NE

Hours

$8: 00-5: 00$

( $7: 30-4: 30$ summer)

Monday through Friday

Purpose of Wells (Holes)

Oil and gas: 75 percent

Water: 23 percent

Mining: 1 percent

Construction: 1 percent

\section{Area Represented}

Nebraska: 100 percent

\section{Collection Size}

Core: $\quad 50-500$ locations

Core chips: Less than 50 locations

Cuttings: $\quad 10,000-50,000$ locations

Growth rate: $300-500$ locations per year
Catalog

Information is on index cards and computer data base (partial), and includes location, type of sample, and footage represented. Catalog is not available for distribution.

\section{Additional Information Available}

Logs. Call for details.

\section{Facilities and Services}

Facility occupies 5,800 square feet in concrete and masonry building with heat, air conditioning, electricity, telephone, and restrooms. Examination room is 300 square feet with

binocular and petrographic microscopes and testing chemicals. Retrieval and replacement of material are provided.

\section{Curation Policy}

User fees: No

Sampling of material: Under some circumstances. Call for details.

Loan of material: Yes

Facility is accepting new material; State law requires accepting samples from oil and gas tests. Material can be kept confidential for 1 year. 
Name, Mailing Address, Telephone

Nevada Bureau of Mines and Geology Scrugham Building

University of Nevada

Reno, NV 89557

702-784-6691

\section{Location or Street Address}

Two storage buildings, off Evans Avenue on University campus Reno, NV

Hours

$8: 00-4: 30$

Monday through Friday

By appointment

\section{Purpose of Wells (Holes)}

$\begin{array}{ll}\text { Mining: } & 60 \text { percent } \\ \text { Oil and gas: } & 40 \text { percent }\end{array}$

Area Represented

Nevada: $\quad 100$ percent

\section{Collection Size}

Core: $\quad 50-500$ locations

Core chips: Less than 50 locations

Cuttings: Less than 500 locations

Growth rate: 30 locations per year

\section{Catalog}

Information is on lists, and includes location, type of sample, and footage represented. Catalog is available for sale.

\section{Additional Information Available}

Photographs (limited in number), logs, analyses. Call for details.

\section{Facilities and Services}

Facility occupies 6,000 square feet in corrugated-steel buildings with electricity. Examination room is 150 square feet with binocular microscopes. Retrieval, replacement, slabbing, and trimming of material are provided.

\section{Curation Policy}

User fees: No

Sampling of material: No

Loan of material: No

Facility is accepting new material;

logs are required. Material from oil and gas tests can be kept confidential for 6 months. Call for details.

\section{Remarks}

Descriptive literature is available. 
Name, Mailing Address, Telephone

New Mexico Bureau of Mines and

Mineral Resources

Campus Station

Socorro, NM 87801

505-835-5402

\section{Location or Street Address}

Workman Center Building

Campus Drive

Socorro, NM

\section{Hours}

$8: 00-12: 00,1: 00-5: 00$

Monday through Friday

Advance notice necessary for

examination of cores

\section{Purpose of Wells (Holes)}

$0 i 1$ and gas: 90 percent

Water: 9 percent

Mining: 1 percent

Area Represented

New Mexico: 100 percent

Collection Size

Core: 50-500 locations

Core chips: Less than 50 locations

Cuttings: $\quad 10,000-50,000$ locations

Growth rate: 180 locations per year
Catalog

Information is on index cards, and includes location, type of sample, and footage represented. Parts of catalog are available for distribution.

\section{Additional Information Available}

Photographs, logs, thin sections (limited in number). Call for details.

\section{Facilities and Services}

Facility nccupies 3,000 square feet (cores) and 5,800 square feet

(cuttings) in corrugated-steel buildings with heat, air conditioning, electricity, telephone, and restrooms. Examination rooms are 360 square feet (cores) and 392 square feet (cuttings) with binocular microscopes. Retrieval and replacement of material are provided for cuttings.

\section{Curation Policy}

User fees: No

Sampling of material: Under some circumstances. Call for details.

Loan of material: Yes

Facility is accepting new material. Material can be kept confidential for 1 year. 
Name, Mailing Address, Telephone

New York State Geological Survey Room 3140

Cultural Education Center

Empire State Plaza

Albany, NY 12230

518-474-5816

Location or Street Address

Cuttings--same as above

Cores--Rotterdam, NY

$$
\because \quad \text { Hours }
$$

8:00-4:00

Monday through Friday

By appointment

\section{Purpose of Wells (Holes)}

Oil and gas: 60 percent

Mining: $\quad 30$ percent

Construction: 5 percent

Disposal: $\quad 5$ percent

\section{Area Represented}

New York: $\quad 100$ percent

\section{Collection Size}

Core: $\quad 50-500$ locations

Core chips: None

Cuttings: $\quad 500-2,000$ locations

Growth rate: Not reported
Catalog

Collection is not cataloged.

Additional Information Available

Logs. Call for details.

\section{Facilities and Services}

Facility (cores) occupies 3,000 square feet in masonry building with heat (to $45^{\circ} \mathrm{F}$ ), electricity, telephone, and restrooms. Examination room is 200 square feet with binocular microscopes to be made available. Retrieval and replacement of material are provided. Cuttings are housed in the offices of the State Geological Survey.

\section{Curation Policy}

User fees: No

Sampling of material: Yes

Loan of material: Yes

Policy for accepting new material is presently under review. Call for details. Material can be kept confidential.

\section{Remarks}

Core collection is housed in Rotterdam, New York, about 20 miles from the Albany offices. 
Name, Mailing Address, Telephone

Lamont-Doherty Geological Observatory Deep-Sea Sample Repository

Palisades, NY 10964

914-359-2900

\section{Location or Street Address}

On Route 9W, one-fourth mile south of Oak Tree Road

Palisades, NY

9:00-5:00

Monday through Friday

Advance notice necessary

\section{Purpose of Wells (Holes)}

Scientific research:

99 percent

(marine-sediment coring

and dredging; onshore drilling)

0 il and gas:

1 percent

\section{Area Represented}

Offshore: 90 percent

Onshore: 10 percent

\section{Collection Size}

Core: $\quad$ More than 10,000

$$
\text { locations }
$$

Core chips: None

Cuttings: Less than 500 locations

Growth rate: 150 locations per year

\section{Catalog}

Information is on lists and computer data base, and includes location, depth, type of sample, footage represented, bottom age, prior sampling, geologic data, and megascopic description. Catalog is available for distribution at cost. Detailed core data are available in a 700-volume chronology. A computer search can be made at cost for cores that have specific physical or sedimentary characteristics.
Additional Information Available

Photographs, logs, analyses. Call for details.

\section{Facilities and Services}

Facility occupies 6,500 square feet in masonry building with heat, air conditioning, electricity, telephone, and restrooms. Examination room is 530 square feet with binocular and petrographic microscopes, trim saw, testing chemicals, camera, thinsection equipment, $x$-radiograph, standard sampling equipment, and library facilities. Retrieval, replacement, slabbing, and trimming of material are provided.

\section{Curation Policy}

User fees: Yes

Sampling of material: Yes

Loan of material: Yes

Facility is accepting nonproprietary material applicable to current research and programs. Material generally is not kept confidential.

\section{Remarks}

Descriptive literature is available. Repository is administratively separate from that of the Deep-Sea Drilling Project (GLOMAR CHALLENGER) described on following page. 


\section{Name, Mailing Address, Telephone}

Lamont-Doherty Geological Observatory Deep-Sea Drilling Project

East Coast Repository

Palisades, NY 10964

914-359-2900

\section{Location or Street Address}

On Route 9w, one-fourth mile south of Oak Tree Road

Palisades, NY

\section{Hours}

9:00-5:00

Monday through Friday

Advance notice necessary

Purpose of Wells (Holes)

Scientific research

(deep-sea drilling): 100 percent

\section{Area Represented}

Offshore: $\quad 100$ percent

\section{Collection Size}

Core: $\quad 500-2,000$ locations

Core chips: Less than 50 locations

Cuttings: Less than 500 locations

Growth rate: None

\section{Catalog}

Information is on computer data base, and includes location, depth, type of sample, and footage represented.

Catalog is available for distribution.

\section{Additional Information Available}

Photographs, logs (limited in number), analyses, thin sections, smear slides. $\mathrm{Call}$ for details.

\section{Facilities and Services}

Facility occupies masonry building with heat, air conditioning, electricity, telephone, and restrooms. Examination room is 1,325 square feet with binocular and petrographic microscopes. Retrieval, replacement, slabbing, and trimming of material are provided.

\section{Curation Policy}

User fees: No

Sampling of material: Yes

Loan of material: Yes

Collection is static because drilling ceased at conclusion of Leg 96 . Material is not kept confidential.

\section{Remarks}

Facility houses deep-sea drilling samples collected by GLOMAR CHALLENGER. Descriptive literature is available. Samples collected by GLOMAR CHALLENGER are also housed at Scripps Institution of Oceanography, California (see California). Repository is administratively separate from that of the Deep-Sea Sample Repository described on preceding page. 
Name, Mailing Address, Telephone

North Carolina Geological Survey 4100 Reedy Creek Road

Raleigh, NC 27607

919-733-7353

Location or Street Address

Same as above

Hours

$8: 00-5: 00$

Monday through Friday

Advance notice necessary

Purpose of Wells (Holes)

Water: $\quad 50$ percent

$0 i 1$ and gas: 20 percent

Mining: 20 percent

Stratigraphic: 10 percent

\section{Area Represented}

North Carolina: 100 percent

\section{Collection Size}

Core: Less than 50 locations

Core chips: Less than 50 locations

Cuttings: Less than 500 locations

Growth rate: 25 locations per year

\section{Catalog}

Information is on index cards and lists, and includes location and footage represented. Catalog is available for distribution.

Additional Information Available

Logs. Call for details.

\section{Facilities and Services}

Facility occupies 1,200 square feet in corrugated-steel building with heat, electricity, telephone, and restrooms. Examination room is 200 square feet. No equipment or user services are provided.

\section{Curation Policy}

User fees: No

Sampling of material: Under some circumstances. Call for details.

Loan of material: Under some circumstances. Call for details.

Facility is accepting new material from State ground-water drilling, oil and gas tests (mandatory), and donations. Material can be kept confidential for 1-2 years. 


\section{Name, Mailing Address, Telephone}

North Dakota Geological Survey Wilson M. Laird Core and Sample

Library

University Station

Grand Forks, ND 58202

701-777-2231.

\section{Location or Street Address}

On campus, across street from Leonard

Hall, University of North Dakota Grand Forks, ND

\section{Hours}

8:00-5:00

Monday through Friday

\section{Purpose of Wells (Holes)}

Oil and gas: 99 percent

Water, coal,

construction: 1 percent

\section{Area Represented}

North Dakota: 100 percent

\section{Collection Size}

Core: $\quad 2,000-10,000$ locations

Core chips: 500-2,000 locations

Cuttings: $\quad 10,000-50,000$ locations

Growth rate: 500 locations per year

\section{Catalog}

Information is on index cards, and includes location, formation name, depth, and type of sample. Catalog is not available for distribution.
Additional Information Available

Logs, analyses, thin sections, water chemistry, drill-stem-test data.

Call for details.

\section{Facilities and Services}

Facility occupies 18,000 square feet in concrete building with heat, air conditioning, electricity, telephone, and restrooms. Examination room is 1,000 square feet with binocular and petrographic microscopes, trim saw and plugger, testing chemicals, and thin-section equipment. Retrieval, replacement, slabbing, and trimming of material are provided.

\section{Curation Policy}

User fees: No

Sampling of material: Yes

Loan of material: No

Facility is accepting new material; State law requires operators to submit cores and cuttings to State Geologist when requested. Material can be kept confidential.

\section{Remarks}

Offices of the North Dakota Geological Survey, including a complete library of geophysical well logs, well records, and production and engineering data, are directly across the street in Leonard Hall. Survey staff is available to answer user questions. Descriptive literature is available. 
Name, Mailing Address, Telephone

Ohio Department of Natural Resources Division of Geological Survey

Subsurface Geology Section

Fountain Square, Building B

Columbus, OH 43224

614-265-7054

\section{Location or Street Address}

1500 Dublin Road

Columbus, $\mathrm{OH}$

Hours

8:00-5:00

Monday through Friday

Advance notice necessary

\section{Purpose of Wells (Holes)}

Oil and gas: 99 percent

Water:

1 percent

Area Represented

Ohio: $\quad 100$ percent

\section{Collection Size}

Core: $\quad 50-500$ locations

Core chips: Less than 50 locations

Cuttings: $2,000-10,000$ locations

Growth rate: 30 locations per year

\section{Catalog}

Information is on index cards and lists, and includes location, formation name, depth, and type of sample. Catalog is available for distribution.

Additional Information Available

Logs. Call for details.

\section{Facilities and Services}

Facility occupies 5,000 square feet in corrugated-steel building with heat, electricity, and restroom. Binocular microscopes are available. There is no separate examination room. Retrieval and replacement of material are provided.

\section{Curation Policy}

User fees: No

Sampling of material: No

Loan of material: Under some circumstances. Call for details.

Facility is accepting new material. Material can be kept confidential for 1 year.

\section{Remaj ks}

Division's subsurface material is divided into two groups. Cores related to coal, water, and mining are housed in a separate facility (see following page). 
Name, Mailing Address, Telephone

Ohio Department of Natural Resources Division of Geological Survey

Regional Geology Section

Fountain Square, Building B

Columbus, OH 43224

614-265-6596

\section{Location or Street Address}

Same as above

\section{Hours}

8:00-5:00

Monday through Friday

Advance notice necessary

\section{Purpose of Wells (Holes)}
Coal:
80 percent
Water:
15 percent
Mining:
5. percent

\section{Area Represented}

Ohio:

100 percent

\section{Collection Size}

\section{Core: $\quad 50-500$ locations}

Core chips: None

Cuttings: None

Growth rate: 15 locations per year

\section{Catalog}

Information is listed by county, and includes location, formation age, and footage represented. Catalog is available for distribution.

\section{Additional Information Available}

Logs, analyses (limited in number). Call for details.

\section{Facilities and Services}

Facility occupies 5,000 square feet in masonry building with lights. There is no examination room, and no equipment is available. Retrieval and replacement of material are provided.

\section{Curation Policy}

User fees: Yes

Sampling of material: No

Loan of material: Under some circumstances. Call for details.

Facility is not accepting new material. Core information can be kept confidential until published.

\section{Remarks}

Division's subsurface material is divided into two groups. Cores and cuttings related to oil and gas are housed in a separate facility (see preceding page). 
Name, Mailing Address, Telephone

Oklahoma Geological Survey

Core and Sample Library

2725 Jenkins Avenue

Norman, OK 73019

405-325-4386

Location or Street Address

Same as above

\section{Hours}

8:00-5:00

Monday through Friday

\section{Purpose of Wells (Holes)}

Oil and gas: 85 percent

Mining: $\quad 10$ percent

Coal: 4 percent

Construction: 1 percent

$\begin{array}{ll} & \text { Area } \\ \text { Oklahoma : } & 100 \text { percent } \\ & \\ & \text { Collection Size } \\ \text { Core: } & \text { Not reported } \\ \text { Core chips: } & \text { Not reported } \\ \text { Cuttings: } & \text { Not reported } \\ \text { Growth rate: } & \text { Not reported }\end{array}$

Facilities and Services

Facility occupies 17,000 square feet in wood building with electricity, telephone, and restrooms. Examination room is 260 square feet with trim saw. Slabbing and trimming of material are provided.

\section{Curation Policy}

User fees: Yes

Sampling of material: Yes

Loan of material: Yes

Facility is accepting new material. Material can be kept confidential for 1 year:

\section{Remarks}

Descriptive literature is available. 
Name, Mailing Address, Telephone

Oregon Department of Geology and

Mineral Industries

State of Oregon Well Sample

Collection

1005 State Office Building

Portland, OR 97201

503-229-5580

\section{Location or Street Address}

NW 8th and Flanders Street

Portland, OR

\section{Hours}

9:00-4:00

Monday through Friday

Advance notice necessary

\section{Purpose of Wells (Holes)}

Oil and gas: 80 percent

Geothermal: 20 percent

\section{Area Represented}

Oregon: $\quad 100$ percent

\section{Collection Size}

Core: Not reported

Core chips: Not reported

Cuttings: Not reported

Growth rate: 20 locations per year
Catalog

Information is on index cards and lists, and includes location and type of sample. Catalog is available for sale.

\section{Additional Information Available}

Logs. Call for details.

\section{Facilities and Services}

Facility occupies 400 square feet in wood and masonry building with heat, electricity, and restrooms. Examination room is 150 square feet with no equipment available. Retrieval and replacement of material are provided.

\section{Curation Policy}

User fees: No

Sampling of material: Yes

Loan of material: No

Facility is accepting new material; samples from all new oil, gas, and geothermal tests deeper than 2,000 feet are added to collection. Oil and gas samples can be kept confidential for 2 years, and geothermal samples for 4 years. 
Name, Mailing Address, Telephone

Pennsylvania Geological Survey

7th Floor, Highland Building

121 South Highland Avenue

Pittsburgh, PA 15206

412-665-2155

Location or Street Address

Sample repository--same as above Core repository--Raccoon Creek State Park (Beaver County), 35 miles east of Pittsburgh, PA

\section{Hours}

8:00-4:00 (both repositories)

Monday through Friday

Advance notice necessary for core

repository

\section{Purpose of Wells (Holes)}

0il and gas: 99 percent

Coal:

1 percent

Area Represented

$\begin{array}{ll}\text { Pennsylvania: } & 99 \text { percent } \\ \text { Ohio, New York, } & \\ \text { West Virginia: } & 1 \text { percent }\end{array}$

Collection Size

Core: Less than 50 locations

Core chips: None

Cuttings: Not reported

Growth rate: Less than 5 locations per year

\section{Catalog}

Information is on index cards (samples) and lists (cores), and includes location, footage represented, total depth, operator, and farm name. Core catalog is available for distribution; sample catalog is not.

\section{Additional Information Available}

Logs, analyses, thin sections. Call for details.

\section{Facilities and Services}

Core repository occupies 300 square feet in concrete garage. A table is available for preliminary examination, but core is usually taken back to Highland Building for detailed study. A new sample repository is under construction across the street from Highland Building; details are not finalized as of August, 1984. Retrieval and replacement of material, and transportation to core library from Survey offices are provided.

\section{Curation Policy}

User fees: No

Sampling of material: Yes

Loan of material: Yes

Facility is accepting new material from wildcat wells. Material can be kept confidential for 1 year, with extension upon request. 
Name, Mailing Address, Telephone

South Carolina Geological Survey

Harbison Forest Road

Columbia, SC 29210

803-758-6431

\section{Location or Street Address}

Same as above

\section{Hours}

8:30-5:00

Monday through Friday

Advance notice necessary

Purpose of Wells (Holes)

\section{Water:}

60 percent

Mining:

20 percent

Construction: 20 percent

\section{Area Represented}

South Carolina: 100 percent

\section{Collection Size}

Core: 50-500 locations

Core chips: Less than 50 locations

Cuttings: Less than 500 locations

Growth rate: Not reported

\author{
Catalog \\ Collection is not cataloged.
}

\section{Additional Information Available}

Logs. Call for details.

\section{Facilities and Services}

Facility occupies 3,000 square feet in corrugated-steel building with electricity. Heated and airconditioned examination room is 300 square feet with binocular and petrographic microscopes, and trim saw. Retrieval and replacement of material are provided.

\section{Curation Policy}

\section{User fees: No}

Sampling of material: Under some circumstances. Call for details.

Loan of material: Yes

Facility is accepting new material. Material can be kept confidential. 
Name, Mailing Address, Telephone

South Dakota Geological Survey

Science Center

University Campus

Vermillion, SD 57069

605-624-4471

Location or Street Address

Same as above

Hours

8:00-5:00

Monday through Friday

Purpose of Wells (Holes)

$0 i 1$ and gas: 80 percent

Water: 20 percent

Area Represented

South Dakota: 100 percent

Collection Size

Core: $\quad 50-500$ locations

Core chips: 50-500 locations

Cuttings: $\quad 500-2,000$ locations

Growth rate: 30 locations per year
Catalog

Information is on lists, and includes location, formation name, depth, type of sample, and formation tops. Catalog is not available for distribution.

\section{Additional Information Available}

Logs, analyses. Call for details.

\section{Facilities and Services}

Facility occupies 1,600 square feet in masonry building with heat, air conditioning, electricity, telephone, and restrooms. Examination room is 100 square feet with binocular microscopes and testing chemicals. No user services are provided.

\section{Curation Policy}

User fees: No

Sampling of material: No

Loan of material: If test results are returned for files.

Facility is accepting new material, including cuttings from all oil and gas tests drilled in State. Material can be kept confidential for 6 months. A 6-month extension can be requested. 
Name, Mailing Address, Telephone

Texas Bureau of Economic Geology

Well Sample Library

10,100 Burnet Road

Austin, TX 78758

512-835-3042

\section{Location or Street Address}

Same as above

\section{Hours}

8:00-5:00

Monday through Friday

\section{Purpose of Wells (Holes)}

0 il and gas:

Mining:

Water:

Coal:
83 percent

11 percent

5 percent

1 percent

\section{Area Represented}

Texas:

Alaska, Arkansas,

Florida, Louisiana: 1 percent

\section{Collection Size}

Core: $\quad 2,000-10,000$ locations

Core chips: 50-500 locations

Cuttings: More than 50,000

locations

Growth rate: 1,000 locations per year

\section{Catalog}

Information is on index cards, lists, and computer data base, and includes formation name, type of sample, footage represented, county, and operator. Catalog is available for sale. A computer search can be made using catalog parameters. Computer is also used for check-ins, check-outs, sample reservations, and return notices.

\section{Additional Information Available}

Driller's logs, scout tickets. Call for details.

\section{Facilities and Services}

Facility occupies 33,000 square feet in masonry and corrugated-steel building with electricity, telephone, and restrooms. Examination room is 400 square feet with binocular and petrographic microscopes, trim saw and plugger, testing chemicals, camera, and thin-section equipment. Retrieval, replacement, slabbing, and trimming of material, and photostatic copying (for a fee) are provided.

A new facility will be available in early 1985. Warehouse will be 107,000 square feet. A 17,500-square-foot building will house examination rooms, saw rooms, cuttings-processing room, and a special processing room with vacuum bombs, oven, and 100-squarefoot walk-in freezer.

\section{Curation Policy}

User fees: No

Sampling of material: Under some circumstances. Call for details.

Loan of material: Yes

Facility is accepting new material; washed cuttings from Texas and surrounding States are particularly sought. Material can be kept confidential for 18 months. 
Name, Mailing Address, Telephone

Utah Geological and Mineral Survey 606 Blackhawk Way

Salt Lake City, UT 84108

$801-581-6831$

\section{Location or Street Address}

Same as above

\section{Hours}

$8: 00-5: 00$

Monday through Friday

Advance notice necessary

\section{Purpose of Wells (Holes)}

0il and gas: 99 percent

Coal: 1 percent

Area Represented

Utah :

90 percent

Colorado: $\quad 5$ percent

Wyoming: $\quad 5$ percent

\section{Collection Size}

Core: Not reported

Core chips: Not reported

Cuttings: Not reported

Growth rate: 20 locations per year
Catalog

Information is on index cards, and includes location, type of sample, and footage represented. Catalog is not available for distribution.

\section{Additional Information Available}

Logs, analyses. Call for details.

\section{Facilities and Services}

Facility occupies 4,000 square feet in masonry building with heat, electricity, and restrooms. Status of examination room is not reported. Retrieval and replacement of material are provided.

\section{Curation Policy}

User fees: No

Sampling of material: Yes

Loan of material: Yes

Facility is accepting new material. Material can be kept confidential. 
Name, Mailing Address, Telephone

Virginia Division of Mineral Resources

P.0. Box 3667

Charlottesville, VA 22903

804-293-5121

Location or Street Address

Same as above

Hours

$8: 30-4: 30$

Monday through Friday

Purpose of Wells (Holes)

\section{Water:}

88 percent

Oil and gas:

Stratigraphic:

9 percent

2 percent

Mining, construction: 1 percent

\section{Area Represented}

Virginia:

100 percent

\section{Collection Size}

Core: Less than 50 locations Core chips: Less than 50 locations Cuttings: 2,000-10,000 locations

Growth rate: 100 locations per year

\section{Catalog}

Information is on lists, and includes location, footage represented, and, for oil and gas tests, formation name, depth, and type of sample. Catalog of material from oil and gas tests is available for distribution.

\section{Additional Information Available}

Photographs (limited in number), logs, thin sections (limited in number), scout tickets. Call for details.

\section{Facilities and Services}

Facility occupies four rooms totaling 1,800 square feet in concrete and masonry building with heat, air conditioning (one room), electricity, telephone, and restrooms. Binocular and petrographic microscopes are available. There is no separate examination room. Retrieval and replacement of material are provided.

\section{Curation Policy}

User fees: No

Sampling of material: No

Loan of material: No

Facility is accepting new material, as provided by industry. Material from oil and gas tests can be kept confidential for 90 days. 
Name, Mailing Address, Telephone

Washington Department of

Natural Resources

Geology and Earth Resources Division Olympia, WA 98501

206-459-6372

Location or Street Address

4224 6th Avenue SE

Lacey, WA

Hours

$8: 00-4: 30$

Monday through Friday

Advance notice preferred

Purpose of Wells (Holes)

0il and gas: 100 percent

Area Represented

Washington: 100 percent

\section{Collection Size}

Core: Less than 50 locations

Core chips: Less than 50 locations

Cuttings: Less than 500 locations

Growth rate: 3 locations per year

\section{Catalog}

Information is on lists, and includes location, type of sample, and footage represented. Catalog is available for distribution.

\section{Additional Information Available}

Logs, analyses, micropaleontology data. Call for details.

\section{Facilities and Services}

Facility occupies 450 square feet in wood building with electricity. Examination room is 35 square feet with no equipment available. Retrieval, replacement, slabbing, and trimming of material are provided.

\section{Curation Policy}

User fees: No

Sampling of material: Yes

Loan of material: Yes

Facility is accepting new material, as required by State law, from oil and gas tests. Material can be kept confidential for 1 year. 
Name, Mailing Address, Telephone

West Virginia Geological Survey Sample Library

P.0. Box 879

Morgantown, WV 26507

304-594-2331

\section{Location or Street Address}

West Virginia Geological Survey Annex, on the Mileground adjacent to

University motor pool

Morgantown, wV

Hours

8:00-5:00

Monday through Friday

By appointment

\section{Purpose of Wells (Holes)}

Oil and gas: 100 percent

\section{Area Represented}

West Virginia: 100 percent

\section{Collection Size}

Core: 50-500 locations

Core chips: Less than 50 locations

Cuttings: $\quad 2,000-10,000$ locations

Growth rate: Less than 50 locations per year

\section{Catalog}

Information is on index cards and computer data base, and includes location, formation name, depth, type of sample, and footage represented. Catalog is available for distribution. Collection is also described in West Virginia Geological Survey Mineral Resource Series \#6, available from the Survey.

\section{Additional Information Available}

Photographs, logs, analyses, thin sections (all limited in number). Call for details.

\section{Facilities and Services}

Facility occupies 4,000 square feet in steel building with heat, electricity, telephone, and restrooms.

Examination room is 1,000 square feet with binocular microscopes and trim saw. Retrieval and replacement of material are provided; slabbing and trimming are provided at user's expense.

\section{Curation Policy}

User fees: No

Sampling of material: Yes.

Loan of material: No

Facility is accepting new material. Material can be kept confidential for as long as 3 years, subject to yearly review. 


\section{WISCONSIN}

Name, Mailing Address, Telephone

Wisconsin Geological and

Natural History Survey

Sample Repository

1815 University Avenue

Madison, WI 53705

608-262-1705

Location or Street Address

1923 East Kenilworth Place

Milwaukee, WI

Hours

First week of each month only

9:00-5:00

Monday through Friday

By appointment

\section{Purpose of Wells (Holes)}

Water:

Mining:

52 percent

Stratigraphic:

45 percent

2 percent

Construction, oil and gas: 1 percent

Area Represented

Wisconsin:

Illinois, Iowa:

99 percent

1 percent

\section{Collection Size}

Core: $\quad 50-500$ locations

Core chips: Not reported

Cuttings: $\quad 10,000-50,000$ locations

Growth rate: 280 locations per year

\section{Catalog}

Information is on lists and computer data base, and includes location, type of sample, and footage represented.

\section{Additional Information Available}

Logs, thin sections (limited in number). Call for details.

\section{Facilities and Services}

Facility occupies 30,000 square feet in concrete building with heat, electricity, telephone, and restrooms. Examination room is 5,000 square feet with binocular microscopes. Retrieval, replacement, slabbing, and trimming of material are provided.

\section{Curation Policy}

User fees: Yes

Sampling of material: Yes

Loan of material: Yes

Facility is accepting new material. State law requires submittal of water-well samples; donations from selected locations are solicited. Material can be kept confidential.

\section{Remarks}

Descriptive literature is available. 


\section{PART II}

Abridged descriptions of sample and core repositories, by State, in the United States.

These facilities serve primarily the administrating agency, but admit individuals who have a legitimate interest in the collection. 
Name, Mailing Address, Telephone

U.S. Army Corps of Engineers

Little Rock District

Geotechnical Branch

Core Repository

P.0. Box 867

Little Rock, AR 72203

501-378-5665

Location or Street Address

Building 1151

Fort Chaffee, AR

(About 200 miles from Little Rock)

Purpose of Wells (Holes)

Construction: 100 percent

Area Represented

Arkansas: $\quad 60$ percent

Missouri: $\quad 40$ percent

\section{Collection}

Core: $\quad 500-2,000$ locations

Core chips: None

Cuttings: None

Cataloged: Yes

Additional Information Available

Photographs, logs, analyses. Call

for details.

\section{Pacilities}

Facility occupies 1,300 square feet in wood building with electricity. There is no examination room, and no equipment is available. 
Name, Mailing Address, Telephone

University of California

Department of Geology and Geophysics

Museum of Geology

Berkeley, CA 94720

415-642-4330

Location or Street Address

Earth Sciences Building

University of California

Berkeley, CA

\section{Purpose of Wells (Holes)}

Mining: $\quad 80$ percent

Construction: $\quad 10$ percent

0 il and gas: 8 percent

Scientific research: 2 percent

\section{Area Represented}

Not reported

\section{Collection}

Core: Not reported

Core chips: Not reported

Cuttings: Not reported

Cataloged: Yes

\section{Additional Information Available}

Not reported
Facilities

Collection is housed in concrete building with heat, electricity, telephone, and restrooms. Binocular and petrographic microscopes are available. There is no separate examination room.

\section{Remarks}

The Museum of Geology is a small research and educational facility. Cores and cuttings are a modest portion of the collection, and are not curated separately. 
Name, Mailing Address, Telephone

Colorado School of Mines

Department of Geology

Core Library

Golden, Co 80401

303-273-3033

Location or Street Address

Green Center

Colorado School of Mines

Golden, CO

\section{Purpose of Wells (Holes)}

0 il and gas: 100 percent

\section{Area Represented}

$\begin{array}{ll}\text { Wyoming: } & 35 \text { percent } \\ \text { Colorado: } & 25 \text { percent } \\ \text { North Dakota: } & 25 \text { percent } \\ \text { Other: } & 15 \text { percent }\end{array}$

\section{Collection}

Core: Not reported

Core chips: Less than 50 locations

Cuttings: Less than 500 locations

Cataloged: No

\section{Additional Information Available}

Logs. Call for details.

\section{Facilities}

Collection is housed in concrete building with heat, air conditioning, electricity, telephone, and restrooms. Examination room (size not reported) has some equipment available by appointment.

\section{Remarks}

Facility is primarily for teaching; most use is class-related. 
Name, Mailing Address, Telephone

Fort Lewis College

Department of Geology

Four Corners Geological Repository

Durango, CO 81301

$303-247-7438$

\section{Location or Street Address}

Same as above

\section{Purpose of Wells (Holes)}

Oil and gas (and $\mathrm{CO}_{2}$ ): 100 percent

\section{Area Represented}

$\begin{array}{lr}\text { New Mexico } & 60 \text { percent } \\ \text { Utah } & 20 \text { percent } \\ \text { Colorado: } & 15 \text { percent } \\ \text { Arizona: } & 5 \text { percent }\end{array}$

\section{Collection}

Core: 50-500 locations

Core chips: 50-500 locations.

Cuttings: $\quad 2,000-10,000$ locations

Cataloged: Yes

Additional Information Available

Logs. Call for details.

\section{Facilities}

Collection is housed in

50,000-square-foot corrugated-steel building with heat, electricity, and restrooms. Examination space is 600 square feet with binocular microscopes available.

\section{Remarks}

Material is from San Juan and Paradox basins. 
Name, Mailing Address, Telephone

University of Miami

4600 Rickenbacker Causeway

Miami, FL 33149

305-361-4670

Location or Street Address

Same as above

\section{Purpose of Wells (Holes)}

Scientific research

(marine-sediment

coring and dredging): 100 percent

\section{Area Represented}

Offshore: 100 percent

\section{Collection}

Core: $\quad 2,000-10,000$ locations

Core chips: None

Cuttings: None

Cataloged: Yes

Additional Information Available

Photographs, analyses (both limited in number). Call for details.
Facilities

Storage space totals 17,000 cubic feet (of which 8,000 cubic feet is refrigerated) in concrete building with heat, air conditioning, electricity, and restrooms. 
Name, Mailing Address, Telephone

U.S. Geological Survey Water Resources Division

4710 Eisenhower Boulevard, Suite B-5 Tampa, FL 33614

813-228-2124

Location or Street Address

Same as above

\section{Purpose of Wells (Holes)}

$\begin{array}{ll}\text { Water: } & 90 \text { percent } \\ \text { Mining: } & 10 \text { percent }\end{array}$

Area Represented

West-central Florida: 100 percent

\section{Collection}

Core: None

Core chips: None

Cuttings: Less than 500 locations

Cataloged: Yes

Additional Information Available

Logs, analyses (limited in number). Call for details.

\section{Facilities}

Collection occupies 10 square feet in concrete building with electricity and restrooms. Examination room is 100 square feet with binocular microscopes and testing chemicals. 
Name, Mailing Address, Telephone

University of Hawaii

Hawaii Institute of Geophysics

Core Repository and Analysis

Laboratory

2525 Correa Road

Honolulu, HI 96822

808-948-6605

Location or Street Address

Room 300, Marine Science Building

1000 Pope Street

Honolulu, HI

Purpose of Wells (Holes)

Scientific research

(marine-sediment

coring and dredging): 100 percent

\section{Area Represented}

Offshore: 100 percent

\section{Collection}

Core: Not reported

Core chips: Not reported

Cuttings: Not reported

Cataloged: Yes

Additional Information Available

Not reported.

\section{Facilities}

Facility occupies 1,700 square feet in concrete building with air conditioning, electricity, and restrooms. Examination room is 1,700 square feet with trim saw and porositypermeability equipment. Binocular and petrographic microscopes and thin-section equipment are available by appointment. 
Name, Mailing Address, Telephone

Honolulu Board of Water Supply 630 South Beretania Street Honolulu, HI 96843

808-527-5276

Location or Street Address

Kalini Corporation Yard

Kini Street

Honolulu, HI

Purpose of Wells (Holes)

Water: $\quad 100$ percent

\section{Area Represented}

Hawaii: $\quad 100$ percent

\section{Collection}

Core: $\quad 50-500$ locations

Core chips: Less than 50 locations

Cuttings: Less than 500 locations

Cataloged: Yes

\section{Additional Information Available}

Logs, thin sections. Call for details.

\section{Facilities}

Collection is housed in 64-squarefoot tunnel, and in 136-square-foot office with air conditioning, electricity, telephone, and restrooms. Binocular and petrographic microscopes are available. There is no separate examination room.

\section{Remarks}

Storage of material collected for study of Honolulu volcanics. 
Name, Mailing Address, Telephone

State of Hawaii Department of Land and Natural Resources

Division of Water and Land Development

P.0. Box 373

Honolulu, HI 96809

808-548-7539

Location or Street Address

1151 Punchbowl Street

Honolulu, HI

Purpose of Wells (Holes)

Water: $\quad 100$ percent

Area Represented

Hawaii: $\quad 100$ percent

Collection

Core: None

Core chips: None

Cuttings: Less than 500 locations

Cataloged: No

Additional Information Available

None
Pacilities

Not reported

\section{Remarks}

Cuttings from water wells drilled by Division of Water and Land Development. 
Name, Mailing Address, Telephone

Idaho Geological Survey

University of Idaho

Moscow, ID 83843

208-885-7991

\section{Location or Street Address}

Room 332, Morrill Hall

University of Idaho

Moscow, ID

\section{Purpose of Wells (Holes)}

0il and gas: 100 percent

\section{Area Represented}

Idaho:

100 percent

\section{Collection}

Core: None

Core chips: None

Cuttings: Less than 500 locations

Cataloged: Yes

\section{Additional Information Available}

None

\section{Facilities}

Collection occupies 200 square feet in masonry building with heat, air conditioning, electricity, telephone, and restrooms. Binocular microscopes and testing chemicals are available. There is no separate examination room. 


\section{ILLINOIS}

Name, Mailing Address, Telephone

U.S. Army Corps of Engineers

Rock Island District

Geotechnical Branch

Clock Tower Building

Rock Island, IL 61201

309-788-6361

\section{Location or Street Address}

Building 33

Rock Island Arsenal

Rock Island, IL

Purpose of Wells (Holes)

Construction: 100 percent

Area Represented

Iowa, Illinois,

Missouri: 100 percent

\section{Collection}

Core:

Core chips: None

Cuttings: None

Cataloged: Yes

Additional Information Available

Photographs, logs. Call for details.

\section{Facilities}

Facility occupies 5,000 square feet in corrugated-steel building with electricity and telephone. Examination room (size not reported) has binocular microscopes.

\section{Remarks}

Cores from Ordovician through Pennsylvanian limestones, dolomites, sandstones, and shales, at depths less than 100 feet. 
Name, Mailing Address, Telephone

Department of Natural Resources

Louisiana Geological Survey

Well Sample and Core Repository

P.0. Box G, University Station

Baton Rouge, LA 70893

504-342-6754

Location or Street Address

Room 153, Geology Building

Louisiana State University

Baton Rouge, LA

\section{Purpose of Wells (Holes)}

Oil and gas: 100 percent

\section{Area Represented}

Louisiana: 100 percent

\section{Collection}

Core: $\quad 2,000-10,000$ locations

Core chips: 2,000-10,000 locations

Cuttings: $\quad 2,000-10,000$ locations

Cataloged: Yes

Additional Information Available

Logs. Call for details .
Facilities

Facility is closed at present time (August 1984) due to construction which displaced core and sample material. 
Name, Mailing Address, Telephone

Louisiana State University

Institute for Environmental Studies

DOE Salt Dome Core Storage

Baton Rouge, IA 70803

504-388-8521

Location or Street Address

Basement, Atkinson Hall

Louisiana State University

Baton Rouge, IA

Purpose of Wells (Holes)

Applied research

(salt-dome structure

and petrology): 100 percent

Area Represented

Louisiana: $\quad .100$ percent

\section{Collection}

Core and cuttings from two 5,000foot-deep wells; about 2,500 feet of salt core recovered from each well.

Cataloged: Yes

\section{Additional Information Available}

Photographs, logs, analyses, thin sections, sketched features of each core. Call for details.
Facilities

Not reported

\section{Remarks}

Collection is funded by U.S.

Department of Energy (DOE). Users must have DOE clearance to use facility. Call for details. 
Name, Mailing Address, Telephone

U.S. Geological Survey

Louisiana District

Sand Sample Library

P.0. Box 66492

Baton Rouge, LA 70896

504-389-0442

\section{Location or Street Address}

6654 Florida Boulevard

Baton Rouge, LA

\section{Purpose of Wells (Holes)}

Water: $\quad 100$ percent

Area Represented

Louisiana: 100 percent

\section{Collection}

Core: Less than 50 locations

(sidewall cores)

Core chips: None

Cuttings: $\quad 2,000-10,000$ locations

Cataloged: Yes

Additional Information Available

Logs. Call for details.

\section{Remarks}

Collection is maintained primarily for agency use.
Collection occupies 200 square feet in wood building with air conditioning and electricity. There is no examination room, and no equipment is available. 


\section{MASSACHUSETTS}

Name, Mailing Address, Telephone

United States Department of Agriculture

Soil Conservation Service

451 West Street

Amherst, MA 01002

413-256-0441

\section{Location or Street Address}

Same as above

\section{Purpose of Wells (Holes)}

Construction

(dam sites): 100 percent

\section{Area Represented}

Masachusetts: 100 percent

\section{Collection}

Core: $\quad 50-500$ locations

Core chips: None

Cuttings: None

Cataloged: No

\section{Additional Information Available}

Photographs (limited in number), logs. Call for details.

\section{Facilities}

Facility occupies 5,000 square feet in wood and masonry building with electricity. There is no examination room, and no equipment is available. 


\section{MASSACHUSETTS}

Name, Mailing Address, Telephone

Metropolitan District Commission

Water Division--Quabbin Section

485 Ware Road

Belchertown, MA 01007

413-323-7883

Location or Street Address

See "Remarks."

Purpose of Wells (Holes)

Construction

(water projects): 100 percent

\section{Area Represented}

Massachusetts: 100 percent

\section{Collection}

Core: About 2 dozen projects between the Connecticut River and Boston

Core chips: None are represented.

Cuttings: None

Cataloged: No

Additional Information Available

Not reported

\section{Facilities}

See "Remarks."

\section{Remarks}

Material is stored at various locations throughout District; records are kept at several offices. Call for details. 


\section{MASSACHUSETTS}

Name, Mailing Address, Telephone

Massachusetts Department

of Public Works

Research and Materials Division

99 Worcester Street

Wellesley Hills, MA 02181

617-235-6100

\section{Location or Street Address}

Basement and garage

Research and Materials Building

Wellesley Hills, MA

\section{Purpose of Wells (Holes)}

Construction (highway

and bridge projects): 100 percent

Area Represented

Masachusetts :

100 percent

Collection

Core: $\quad$ More than 10,000 locations (estimated)

Core chips: None

Cuttings: None

Cataloged: Partially

Additional Information Available

Logs. Call for details.

\section{Pacilities}

Storage area in masonry building has lights and low ceiling clearance. There is no examination room, and no equipment is available. 


\section{MASSACHUSETTS}

Name, Mailing Address, Telephone

Weston Observatory

381 Concord Road

Weston, MA 02193

617-899-0950

Location or Street Address

Same as above

Purpose of Wells (Holes)

Coral: $\quad 100$ percent

Area Represented

Massachusetts: 100 percent

\section{Collection}

Core: Not reported

Core chips: Not reported

Cuttings: Not reported

Cataloged: Yes

Additional Information Available

Logs, thin sections, coal analyses. Call for details.

\section{Pacilities}

Not reported

\section{Remarks}

Storage of material from Narragansett basin. 
Name, Mailing Address, Telephone

U.S. Geological Survey

Branch of Atlantic Marine

Geology

Sample Repository

Gosnold Building, Quissett Campus

Woods Hole, MA 02543

617-548-8700

\section{Location or Street Address}

Same as above

\section{Purpose of Wells (Holes)}

Scientific research

(marine-sediment coring):

100 percent
Facilities

Collection occupies 600 square feet in portable vans with refrigeration and electricity. Examination room is 150 square feet with no equipment available.

\section{Area Represented}

Offshore: $\quad 100$ percent

\section{Collection}

Core: Less than 50 locations

Core chips: None

Cuttings: None

Cataloged: Yes

Additional Information Available

Photographs, logs, analyses, thin sections. Call for details. 


\section{MICHIGAN}

Name, Mailing Address, Telephone

University of Michigan

Department of Geological Sciences

Subsurface Laboratory

1506 C. C. Little Building

Ann Arbor, MI 48109

313-764-2434

\section{Location or Street Address}

Same as above

\section{Purpose of Wells (Holes)}

Oil and gas: 95 percent

Mining, disposal: 5 percent

\section{Area Represented}

Michigan: 98 percent

Ohio: 1 percent

Ontario: 1 percent

\section{Collection}

Core: $\quad 50-500$ locations

Core chips: 2,000-10,000 locations

Cuttings: Less than 500 locations

Cataloged: Yes

Additional Information Available

Logs. Call for details.

\section{Facilities}

Facility storage area is 1,500 square feet in concrete and masonry building with electricity and restrooms. Examination room is 180 square feet with binocular microscopes, trim saw, testing chemicals, camera, and thinsection equipment. 


\section{MICHIGAN}

Name, Mailing Address, Telephone

Wayne State University

Geology Department

Subsurface Sample Library

201 Old Main

Detroit, MI 48202

313-577-2510

Location or Street Address

Room 61, 01d Main

(Between Warren and Hancock)

Wayne State University

Detroit, MI

\section{Purpose of Wells (Holes)}

$0 i l$ and gas: 100 percent

\section{Area Represented}

Michigan:

Indiana:

98 percent

2 percent

\section{Collection}

Core:

$$
\text { 50-500 locations }
$$

Core chips: Less than 50 locations

Cuttings: $\quad 10,000-50,000$ locations

Cataloged: Yes

Additional Information Available

Iogs. Call for details.

\section{Facilities}

Facility occupies 8,500 square feet in concrete building with heat, electricity, telephone, and restrooms. Examination room is 2,720 square feet with binocular and petrographic microscopes, trim saw and plugger, and thin-section equipment. 
Name, Mailing Address, Telephone

Michigan State University

Department of Geological Sciences Sample Library

206 Natural Science Bldg.

East Lansing, MI 48824

$517-355-4626 / 4631$

\section{Location or Street Address}

Central Services Building

Michigan State University

East Lansing, MI

\section{Purpose of Wells (Holes)}

0il and gas: 95 percent

Coal :

5 percent

Area Represented

Michigan: 95 percent

Indiana, Ohio: 5 percent

\section{Collection}

Core: $\quad 50-500$ locations

Core chips: None

Cuttings: $\quad 10,000-50,000$ locations

Cataloged: Yes

Additional Information Available

Photographs (limited in number),

logs. Call for details.
Facilities

Collection is housed in masonry building with heat, electricity, and restrooms. Examination room is 200 square feet with binocular and petrographic microscopes, trim saw, and core splitter. 
Name, Mailing Address, Telephone

Western Michigan University

Department of Geology

Kalamazoo, MI 49008

616-383-0063

\section{Location or Street Address}

Rood $\mathrm{Hall}$

Western Michigan Avenue and

Marion Street

Western Michigan University

Kalamazoo, MI

\section{Purpose of Wells (Holes)}

0il and gas: 100 percent

$$
\text { Area Represented }
$$

Michigan: 100 percent

\section{Collection}

Core: Less than 50 locations

Core chips: None

Cuttings: None

Cataloged: Yes

\section{Additional Information Available}

None

\section{Facilities}

Collection occupies 200 square feet in concrete building with heat, air conditioning, electricity, telephone, and restrooms. Examination room is 100 square feet with binocular and petrographic microscopes, and testing chemicals.

\section{Remarks}

Collection was begun in 1983;

expansion and increased utilization are sought. 


\section{MICHIGAN}

Name, Mailing Address, Telephone

Central Michigan University

Geology Department

Mount Pleasant, MI 48859

517-774-3179

\section{Location or Street Address}

Room 314, Brooks Hall

Central Michigan University

Mount Pleasant, MI

\section{Purpose of Vells (Holes)}

Oil and gas: 100 percent

\section{Area Represented}

Michigan: 100 percent

\section{Collection}

Core: Less than 50 locations

Core chips: Less than 50 locations

Cuttings: $2,000-10,000$ locations

Cataloged: Yes

Additional Information Available

None

\section{Facilities}

Collection occupies 500 square feet in masonry building with electricity. There is no examination room, and no equipment is available. 


\section{MINHESOTA}

Name, Mailing Address, Telephone

Minnesota Geological Survey

2642 University Avenue

St. Paul, MN 55114

612-373-3372

Location or Street Address

Same as above

\section{Purpose of Wells (Holes)}

Water:

95 percent

Mining:

5 percent

\section{Area Represented}

Minnesota: 100 percent

\section{Collection}

Core: $\quad 50-500$ locations

Core chips: Less than 50 locations

Cuttings: $\quad 500-2,000$ locations

Cataloged: Yes

Additional Information Available

Logs, analyses, thin sections, magnetic-susceptibility and density measurements. Call for details.

\section{Facilities}

Facility occupies 3,500 square feet in concrete building with heat, air conditioning, electricity, telephone, and restrooms. Examination room is 250 square feet with binocular and petrographic microscopes, trim saw, testing chemicals, camera, and thin-section equipment.

\section{Remarks}

Collection is maintained primarily for agency use; the general repository for Minnesota is managed by Department of Natural Resources in Hibbing (see Part I, Minnesota). 


\section{MINNESOTA}

Name, Mailing Address, Telephone

U.S. Army Corps of Engineers

St. Paul District

1135 USPO and Custom House

St. Paul, MN 55101

612-725-7595

\section{Location or Street Address}

Same as above

Purpose of Wells (Holes)

Construction: 100 percent

Area Represented

Minnesota: $\quad 40$ percent

Wisconsin: 40 percent

North Dakota: 20 percent

\section{Collection}

Core: Less than 50 locations

Core chips: None

Cuttings: None

Cataloged : No

Additional Information Available

Photographs (limited in number), logs. Call for details.

\section{Facilities}

Facility occupies 3,000 square feet in wood and masonry building with heat and lights. There is no examination room, and no equipment is available. 
Name, Mailing Address, Telephone

University of Montana

Geology Department

Missoula, MT 59812

406-243-5261

Location or Street Address

Fort Missoula

Missoula, MT

Purpose of Wells (Holes)

Oil and gas: 70 percent

Mining: $\quad 30$ percent

Area Represented

Montana: $\quad 100$ percent

\section{Collection}

Core: Less than 50 locations

Core chips: Not reported

Cuttings: Less than 500 locations

Cataloged: Partially

\section{Additional Information Available}

None
Facilities

Collection is housed in World War II prison cells, with hallway serving as an examination room. Binocular and petrographic microscopes, trim saw, testing chemicals, camera, and thinsection equipment are available. 
Name, Kailing Address, Telephone

U.S. Geological Survey

Geologic Data Center

P.0. Box 327

Mercury, NV 89023

702-986-9260

\section{Location or Street Address}

U.S. Department of Energy (DOE)

Nevada Test Site

Mercury, NV

\section{Purpose of Wells (Holes)}

Nuclear tests (drill holes): 50 percent Nuclear tests (tunnels): 48 percent Water:

\section{Facilities}

Facility occupies 38,000 square feet in concrete and corrugated-steel building with heat, air conditioning, electricity, telephone, and restrooms. Examination room is 3,000 square feet with binocular and petrographic microscopes, trim saw and plugger, testing chemicals, camera, porosity-permeability equipment, magnetometer, ultraviolet light, and core splitter.

\section{Remarks}

Users must have DOE clearance to use facility. Call for details.

\section{Area Represented}

\section{Nevada:}

Alaska, New Mexico,

Mississippi :
99 percent

1 percent

\section{Collection}

Footage represented by core, core chips, and cuttings totals $2,600,000$ feet.

Cataloged: Yes

Additional Information Available Photographs, logs. Call for details. 
Name, Mailing Address, Telephone

U.S. Department of Energy

Waste Isolation Pilot Plant (WIPP)

P.0. Box 2078

Carlsbad, NM 88221

505-887-0586

Location or Street Address

401 North Canal

Carlsbad, NM

Purpose of Wells (Holes)

Applied research: 100 pecent

(geological and hydrological

characterization of WIPP site).

Area Represented

Southeast New Mexico: 100 percent

\section{Collection}

Core: 50-500 locations

Core chips: Less than 50 locations

Cuttings: Less than 500 locations

Cataloged: Yes

Additional Information Available

Photographs, logs, analyses. Call

for details. 


\section{Name, Mailing Address, Telephone}

Battelle Memorial Institute

Office of Nuclear Waste Isolation 505 King Avenue

Columbus, $\mathrm{OH} 43201$

614-424-4406

Location or Street Address

Not reported

Purpose of Wells (Holes)

Applied research: $\quad 100 \%$

(salt-dome structure

and petrology)

\section{Area Represented}

Louisiana: $\quad 100$ percent

\section{Collection}

Core: Not reported

Core chips: Not reported

Cuttings: Not reported

Cataloged: Not reported

Additional Information Available

Not reported

\section{Facilities}

Not reported

\section{Remarks}

Collection is funded by U.S.

Department of Energy (DOE). Users must have DOE clearance to use facility. Call for details. 
Name, Mailing Address, Telephone

University of Toledo

Department of Geology

Subsurface Data Center

Toledo, OH 43606

419-537-2398

\section{Location or Street Address}

Field House and University Hall

University of Toledo

Toledo, $\mathrm{OH}$

\section{Purpose of Wells (Holes)}

0il and gas: 95 percent

Construction: 5 percent

(Collection includes sediment cores from Lake Erie.)

\section{Area Represented}

Ohio:

Indiana:

Michigan:

85 percent

14 percent

1 percent

\section{Collection}

Core: $\quad 50-500$ locations

Core chips: Not reported

Cuttings: $\quad 2,000-10,000$ locations

Cataloged: Yes

Additional Information Available

Logs, analyses, thin sections (all

limited). Call for details.

\section{Facilities}

Collection is housed in concrete building, with heat, electricity, telephone, and restrooms. Examination room is 400 square feet with binocular and petrographic microscopes. 
Name, Mailing Address, Telephone

Oregon State University College of Oceanography Marine Geological Sample Collection Corvallis, OR 97331

503-754-2296

Location or Street Address

Marine Geology Building 30 th and Western Avenue Oregon State University Corvallis, OR

Purpose of Vells (Holes)

Scientific research (marinesediment coring): $\quad 100$ percent

\section{Area Represented}

Primarily eastern Pacific Ocean and Gulf of California.

\section{Collection}

Core: $\quad 500-2,000$ locations

Core chips: Not reported

Cuttings: Not reported

Cataloged: Yes

\section{Additional Information Available}

Photographs, logs, analyses. Call for details.

\section{Facilities}

Facility occupies corrugated-steel building with refrigerated storage, heat, air conditioning, electricity, telephone, and restrooms. Examination room (size not reported) has binocular and petrographic microscopes, trim saw, camera, thin-section equipment, and porosity-permeability equipment. 


\section{PENNSYLVANIA}

Name, Mailing Address, Telephone

Academy of Natural Sciences

of Philadelphia

19th and The Parkway

Philadelphia, PA 19103

215-299-1137

Location or Street Address

Same as above

\section{Purpose of Wells (Holes)}

Water, oil and gas: 100 percent
Facilities

Collection is housed in masonry building with heat, air conditioning, electricity, telephone, and restrooms. Binocular and petrographic microscopes are available. There is no separate examination room.

\section{Remarks}

Work is beginning on reorganization of archived collection.

\section{Area Represented}

$\begin{array}{lr}\text { New Jersey: } & 50 \text { percent } \\ \text { North Carolina: } & 20 \text { percent } \\ \text { Virginia: } & 10 \text { percent } \\ \text { Maryland: } & 10 \text { percent } \\ \text { South Carolina: } & 5 \text { percent } \\ \text { Delaware: } & 3 \text { percent } \\ \text { Georgia: } & 2 \text { percent }\end{array}$

\section{Collection}

Core: Less than 50 locations

Core chips: None

Cuttings: Many (number unknown)

Cataloged: Partially

\section{Additional Information Available}

Academy library is available to users. 
Name, Mailing Address, Telephone

U.S. Department of Interior Office of Surface Mining Technical Services Division Lake Lynn Core Library 10 Parkway Center Pittsburgh, PA 15220 412-937-2868

Purpose of Wells (Holes)

Coal (subsidence, fire, and landslide areas): 100 percent

\section{Area Represented}

Pennsylvania, West Virginia, Alabama, Virginia, Ohio, Indiana, Kentucky, Tennessee, Illinois

\section{Collection}

Core: $\quad 50-500$ locations

Core chips: None

Cuttings: None

Cataloged: No

\section{Additional Information Available}

Photographs, logs, analyses, video tapes. Call for details.

\section{Facilities}

Collection is housed in limestone mine. There is no examination room, and no equipment is available.

\section{Remarks}

Collection is newly established and growing. 


\section{PENNSYLVANIA}

Name, Mailing Address, Telephone

U.S. Army Corps of Engineers

Pittsburgh District

Geotechnical Branch

1928 Federal Building

1000 Liberty Avenue

Pittsburgh, PA 15222

412-644-4124

\section{Location or Street Address}

Neville Island Warehouse

Grand Avenue

Pittsburgh, PA

\section{Purpose of Wells (Holes)}

Construction: 100 percent

\section{Area Represented}

Pennsylvania: 50 percent

West Virginia: 50 percent

\section{Collection}

Core: Less than 50 locations

Core chips: None

Cuttings: None

Cataloged: No

Additional Information Available

Photographs, logs, analyses. Call

for details.

\section{Facilities}

Facility occupies 7,200 square feet in corrugated-steel building with heat and electricity. There is no examination room, and no equipment is available. 
Name, Mailing Address, Telephone

University of Rhode Island

Graduate School of Oceanography

Core Laboratory

Building D-180

Quonset, RI 02852

401-294-2863

Location or Street Address

Same as above

Purpose of Wells (Holes)

Scientific research

(marine-sediment

coring and dredging): 100 percent

\section{Area Represented}

Offshore: 100 percent

\section{Collection}

Core: $\quad 500-2,000$ locations

Core chips: None

Cuttings: None

Cataloged: Yes

\section{Additional Information Available}

Photographs (limited in number), logs, analyses, smear slides, sample descriptions. Call for details.

\section{Facilities}

Facility occupies 1,800 square feet in corrugated-steel building with refrigerated storage, heat, electricity, telephone, and restrooms. Examination room is 800 square feet with binocular microscopes, testing chemicals, and camera. 
Name, Hailing Address, Telephone

Tennessee Division of Geology

701 Broadway

Nashville, TN 37203

615-742-6703

Location or Street Address

See "Facilities."

Purpose of Wells (Holes)

Oil and gas: 95 percent

Mining: 3 percent

Coal: 2 percent

Area Represented

Tennessee: 100 percent

\section{Collection}

Core: Less than 50 locations

Core chips: Not reported

Cuttings: $\quad 500-2,000$ locations

Cataloged: Yes

Additional Information Available

None

\section{Pacilities}

Collection is housed in masonry and corrugated-steel buildings located in Lebanon, Cookeville, Nashville, and other cities. Call for details. 
Name, Mailing Address, Telephone

U.S. Army Corps of Engineers

Nashville District

Geology Section

P.0. Box 1070

Nashville, TN 37202

615-251-5686

\section{Location or Street Address}

Federal Building Annex

8 th and Broadway

Nashville, TN

\section{Purpose of Wells (Holes)}

Construction: 100 percent

\section{Area Represented}

$\begin{array}{ll}\text { Tennessee: } & 40 \text { percent } \\ \text { Kentucky: } & 40 \text { percent } \\ \text { Mississippi : } & 20 \text { percent }\end{array}$

\section{Collection}

Core: $\quad 50-500$ locations

Core chips: None

Cuttings: None

Cataloged: Yes

Additional Information Available

Photographs, logs, analyses. Call

for details.

\section{Pacilities}

Facility occupies 6,000 square feet in masonry building with heat, air conditioning, electricity, and telephone. Examination room is 1,200 square feet with no equipment available. 
Name, Mailing Address, Telephone

Texas A \& M University

Department of Geology

College Station, TX 77843

409-845-2451

\section{Location or Street Address}

Texas A \& M Research Annex

State Highway 21

Bryan, TX

\section{Purpose of Wells (Holes)}

Oil and gas: 95 percent

Coal :

5 percent

\section{Area Represented}

Texas:

Other:

75 percent

25 percent

\section{Collection}

Core: $\quad 500-2,000$ locations

Core chips: Less than 50 locations

Cuttings: Less than 500 locations

Cataloged: Yes

Additional Information Available

Logs, analyses, thin sections

(all limited in number). Call for details.

\section{Facilities}

Facility occupies 1,200 square feet in wood building with lights. There is no examination room, and no equipment is available.

\section{Remarks}

Collection is maintained primarily for use by faculty and students. 
Name, Mailing Address, Telephone

University of Texas at Austin

Institute for Geophysics

Marine Geophysics Laboratory

4920 North Interstate 35

Austin, TX 78751

512-458-4238

Location or Street Address

700 The Strand

Galveston, TX

Purpose of Wells (Holes)

Scientific research

(marine-sediment

coring ):

100 percent

Area Represented

Offshore:

100 percent

\section{Collection}

Core: $\quad 50-500$ locations

Core chips: None

Cuttings: None

Cataloged: Yes

Additional Information Available

X-radiographs, logs, analyses. Call for details.

\section{Facilities}

Collection and examination areas occupy 800 square feet in concrete building with heat, air conditioning, and electricity. No equipment is available. 
Name, Mailing Address, Telephone

University of Utah Research Institute Earth Science Laboratory 420 Chipeta Way, Suite 120

Salt Lake City, UT 84108

$801-581-5283$

Location or Street Address

Major Street

Salt Lake City, UT

\section{Purpose of Wells (Holes)}

Geothermal: $\quad 90$ percent

Mining: $\quad 10$ percent

\section{Area Represented}

Nevada:

Utah:

55 percent

California:

Idaho:

Oregon:
27 percent

10 percent

5 percent
3 percent

\section{Collection}

Core: Less than 50 locations

Core chips: Not reported

Cuttings: Less than 500 locations

Cataloged: Yes

Additional Information Available

Logs. Call for details. 
Name, Mailing Address, Telephone

U.S. Army Corps of Engineers

Norfolk District

Geotechnical Engineering Section

Great Bridge Reservation

803 Front street

Norfolk, VA 23510

804-441-3669

Location or Street Address

Same as above

Purpose of Wells (Holes)

Construction: 100 percent

\section{Area Represented}

Virginia: $\quad 100$ percent

\section{Collection}

Core: Not reported

Core chips: Not reported

Cuttings: Not reported

Cataloged: No

Additional Information Available

Photographs (limited in number), logs, analyses. Call for details.

\section{Facilities}

Collection occupies 1,000 square feet in wood building with electricity. There is no examination room, and no equipment is available. 


\section{WASHINGTON}

Name, Mailing Address, Telephone

Rockwell Hanford Operations

Basalt Waste Isolation Project

P.0. Box 800

Richland, WA 99352

509-376-6265

Location or Street Address

Building 2101-M, 200 East Area

Hanford Site

\section{Purpose of Wells (Holes)}

Applied research

(geological and hydro-

logical characterization

of Hanford Site):

100 percent

\section{Facilities}

Not reported

\section{Remarks}

Users must have clearance from U.S. Department of Energy to use facility. Call for details.

\section{Area Represented}

Southeast Washington: 100 percent

\section{Collection}

Collection is reported as extensive.

Cataloged: Yes

\section{Additional Information Available}

Photographs. Call for details. 


\section{WASHINGTON}

Name, Mailing Address, Telephone

University of Washington, WB-10

School of Oceanography

Seattle, WA 98195

$206-543-5060$

Location or Street Address

Same as above

Purpose of Wells (Holes)

Scientific research

(marine-sediment

coring and dredging): 100 percent

Area Represented

Primarily Pacific and Arctic Oceans

\section{Collection}

Core: Not reported

Core chips: None

Cuttings: None

Cataloged: Yes

\section{Additional Information Available}

None

\section{Facilities}

Collection occupies 400 square feet in concrete building with heat and electricity. Examination room (size not reported) has binocular microscopes and thin-section equipment. 


\section{WISCONSIN}

Name, Mailing Address, Telephone

University of Wisconsin

Geology Repository

1215 West Dayton

Madison, WI 53706

$608-262-8960$

Location or Street Address

Same as above

Scientific research

(marine-sediment

coring):

100 percent

Area Represented

Central Arctic Ocean: 100 percent

\section{Collection}

Core: $\quad 500-2,000$ locations

Core chips: None

Cuttings: None

Cataloged: Yes

\section{Additional Information Available}

Photographs (Iimited in number), logs, analyses, and thin sections (both limited in number). Call for details. 


\section{APPEIDIX}

\section{U.S. Army Corps of Engineers District Offices \\ [Asterisk, *, indicates that repository is described in Part II]}

Mobile District

P.0. Box 2288

Mobile, AL 36628

205-690-2660

Alaska District

P.0. Box 7002

Anchorage, AK 99510

907-752-4942

* Little Rock District

P.0. Box 867

Little Rock, AR 72203

501-378-5665

Los Angeles District

P.0. Box 2711

Los Angeles, CA 90053

213-688-5607

Sacramento District

650 Capitol Mall

Sacramento, CA 95814

916-440-2327

San Francisco District

211 Main Street

San Francisco, CA 94105

415-556-2752

Jacksonville District

P.0. Box 4970

Jacksonville, FL 32201

904-791-2211

Savannah District

P.0. Box 889

Savannah, GA 31402

912-233-8822

Honolulu District

Building 230

Ft. Shafter

Honolulu, HI

808-438-9258
Chicago District

219 South Dearborn Street

Chicago, II 60604

$312-353-6434$

*Rock Island District Clock Tower Building Rock Island, II 61201 309-788-6361

Louisville District

P.0. Box 59

Louisville, KY 40201

502-582-6461

New Orleans District

P.0. Box 60267

New Orleans, LA 70160

504-865-1121

Baltimore District

P.0. Box 1715

Baltimore, MD 21203

301-962-3670

Detroit District

P.0. Box 1027

Detroit, MI 48231

313-226-6813

Kansas City District

700 Federal Building

601 E. 12th Street

Kansas City, MO 64106

816-374-3645

St. Louis District

210 North 12th

St. Louis, MO 63101

314-268-2872

* St. Paul District

1135 USPO \& Custom House

St. Paul, MN 55101

612-725-7595 
Vicksburg District

P.0. Box 60

Vicksburg, MS 39180

601-636-1311

Wilmington District

P.0. Box 1890

Wilmington, NC 28402

919-763-9971

Omaha District

6014 USPO \& Courthouse

$215 \mathrm{~N} .17$ Street

Omaha, NE 68102

402-221-4133

Albuquerque District

P.0. Box 1580

Albuquerque, NM 87103

505-766-2776

Buffalo District 1776 Niagara Street

Buffalo, NY 14207

716-876-5454

New York District

26 Federal Plaza

New York, NY 10007

212-264-3996

Tulsa District

P.0. Box 61

Tulsa, OK 74102

918-581-7351

Portland District

P.0. Box 2946

Portland, OR 97208

503-221-6997

Philadelphia District US Custom House 2nd \& Chestnut Street Philadelphia, PA 19106 215-597-2812

*Pittsburgh District 1928 Federal Building 1000 Liberty Avenue Pittsburgh, PA 15222 412-644-4124
Charleston District

P.0. Box 919

Charleston, SC 29402

803-577-4171

Memphis District

668 Federal office Building

Memphis, TN 38103

$901-521-3471$

* Nashville District

P.0. Box 1070

Nashville, TN 37202

612-251-5686

Ft. Worth District

P.0. Box 17300

Ft. Worth, TX 76102

817-334-2814

Galveston District

P.0. Box 1229

Galveston, TX 77553

$713-763-1211$

*Norfolk District Great Bridge Reservation

803 Front Street

Norfolk, VA 23510

804-441-3669

Seattle District

P.0. Box 3-3755

Seattle, WA 98134

206-764-3495

Walla Walla District

Building 602

City-County Airport

Walla Walla, WA 99362

509-525-5500

Huntington District

P.0. Box 2127

Huntington, WV 25701

304-529-2318 